\title{
Cladocera (Crustacea: Branchiopoda) of Vientiane province and municipality, Laos
}

\author{
Alexey A. KOTOV,, $2^{1,}$ Kay VAN DAMME, ${ }^{1,3}$ Eugeniya I. BEKKER,,${ }^{1,2}$ Somepong SIBOUALIPHA, ${ }^{1}$ \\ Marcelo SILVA-BRIANO, ${ }^{1,4}$ Araceli A. ORTIZ, ${ }^{1,4}$ Ricardo G. DE LA ROSA, ${ }^{4}$ La-orsri SANOAMUANG ${ }^{1}$ \\ ${ }^{1}$ Applied Taxonomic Research Center, Department of Biology, Faculty of Science, Khon Kaen University, Khon Kaen 40002, Thailand; \\ ${ }^{2}$ A.N. Severtsov Institute of Ecology and Evolution, Leninsky Prospekt 33, Moscow 119071, Russia; ${ }^{3}$ Environmental Genomics Group, \\ School of Biosciences, University of Birmingham, B15 2TT Edgbaston, Birmingham, UK; ${ }^{4}$ Centro de Ciencias Básicas, Departamento \\ de Biología, Universidad Autónoma de Aguascalientes, Av. Universidad 940, Ciudad Universitaria, 20131 Aguascalientes, Mexico \\ *Corresponding author: alexey-a-kotov@yandex.ru
}

\begin{abstract}
We present the first faunistic report on the Laotian Cladocera from diverse habitats in Vientiane province, Central Laos. We counted a total of 70 species, belonging to 37 genera, which is realistically close to an estimated 77 species. The five most common species were Diaphanosoma excisum, Ephemeroporus $c f$. barroisi, Anthalona harti, Macrothrix spinosa and Chydorus $c f$. eurynotus. The fauna is typically Oriental/Southeast (SE) Asian, showing a strong similarity with neighbouring countries and especially Thailand. We discussed the current taxonomical status of the species and provided illustrations of the main taxa for future comparison. There are no surprising faunistic elements, except for a few new records for SE Asia (Matralona freyi, Ilyocryptus thailandensis). Our data is preliminary, as the fauna of Laos remains insufficiently studied. As for SE Asia as a whole, a significant number of taxa is in need of taxonomical revision.
\end{abstract}

Key words: Cladocera, Laos, SE Asia, diversity, taxonomy.

Received: March 2013. Accepted: October 2013.

\section{INTRODUCTION}

Taxonomy of the Cladocera (Crustacea: Branchiopoda) as well as many other groups of freshwater microscopic animals was in a very poor state during most of the $20^{\text {th }}$ century, unjustly regarded by many hydrobiologists of that time as archaic and uninteresting (Korovchinsky, 1997). As a result, inadequate determinations compromised subsequent analysis of data dealing with studies at the species level (studies in ecology, biogeography, paleolimnology, etc.). Only in the 60-70s, the level of cladoceran taxonomy began to improve, following the pioneer efforts of David Frey and Nikolai N. Smirnov (Frey, 1959, 1973, 1982a, 1982b; Smirnov, 1966, 1971, 1976). As a result, we know about 700 valid species to date (Kotov, 2011), while at least 2/3-3/4 of the real cladoceran biodiversity is hidden (Adamowicz and Purvis, 2005; Forró et al., 2008) and needs to be studied, i.e. formally described in a descriptive manner which is considered irrelevant by many recent journals. However, this work remains to be done and should be part of a large joint effort (e.g. Frey, 1987).

Groups in tropical zooplankton (including littoral animals), are now under intensive study by morphologists as well as geneticists. Studies of the biodiversity in the Western World almost exclusively concentrate on molec- ular methods, while the centres of the traditional morphological investigations have shifted to the developing countries, mainly Asia and Latin America. In taxonomical aspects, different tropical regions are studied to a very different extent. The best example is probably Mexico (Elías-Gutiérrez et al., 2006, 2008a, 2008b). At the same time, an insufficient level of study in the Oriental region leads to a situation where only 107 valid taxa have been reported, while in the Palaearctic the species number was estimated at about 2.5 times higher (Forró et al., 2008). The latter is unrealistic and it shows the need for continuous effort.

Among Southeast (SE) Asian countries, Thailand has been studied significantly better than others (Pholpunthin, 1997; Sanoamuang, 1998; Maiphae et al., 2005, 2008). There were only a few publications concerning the Cladocera fauna of other countries (Tanaka and Ohtaka, 2010), sometimes outdated (Shirota, 1966; Thanh et al., 1980). Korovchinsky (2013a) summarised the available information on the SE Asian cladocerans and concluded that among 297 formal species recorded from SE Asia, only 67 species could be regarded as good, while others are junior synonyms or taxa with unclear or/and unconfirmed status in SE Asia. We believe that the present volume (the FISA Proceedings), will significantly contribute to our knowledge on the SE Asian cladocerans, including new 
papers by Korovchinsky (2013a) on the Cladocera of complete SE Asia, by Sinev and Korovchinsky (2013) about Vietnam, and by Van Damme et al. (2013) and Van Damme and Maiphae (2013) about new paludal chydorids of South Thailand. The focus of this particular work is situated in a country where faunistics of the cladocerans remained to be carried out.

Lao People's Democratic Republic (Laos) is a landlocked country in the centre of the Indochinese peninsula. The total human population is around 6.5 million, mostly distributed in the valleys of the Mekong river, where rice can be grown, because the dominant economy is represented by agriculture and subsistence farming with a few major urban centres (Wikipedia, 2013). The climate of Central Laos is tropical with a distinct wet season from June to October and a mostly dry season for the rest of year. In the hottest months of March and April, average temperature ranges from 30 to $38^{\circ} \mathrm{C}$ depending on location and altitude. Coolest temperature occurs between November and February and at higher elevations might average $15^{\circ} \mathrm{C}$.

Not a single paper has been published that specifically focuses on the Cladocera of Laos. Heckman (1974) noted on the succession of zooplankton and other freshwater invertebrates in a rice field from Vientane province, Laos and included some cladocerans in his study; Silva-Briano et al. (2005) reported on 31 species in the central part of Laos, during a presentation of the $7^{\text {th }}$ International Symposium on Cladocera; Ponthalith (2006) found 40 species in his Degree Thesis on Champasack province, but these results, or even lists, remained unpublished. Our aim is to make an inventory of the fauna of the cladocerans in Vientiane province, Central Laos.

\section{METHODS}

The main material for this study consists of 76 freshwater sample series (samples per water body on a particular date) collected qualitatively from 48 localities in the basin of Nam Ngum river and reservoir (about $250 \mathrm{~km}^{2}$ ) in Viengkham (37 localities), Phohong (9 localities) and Keo Oudom (2 localities) districts of Vientiane province (Supplementary Tab. 1, Figs. 1-3). The samples were taken during dry (November to December, 2010) and rainy (June to July, 2011) seasons by SS (Fig. 3). The plankton net towed across the water over distances of 20 $\mathrm{m}$ or more for at least 20 times per sampling site; a dip net was used for collecting samples in the littoral zone, both nets have a mesh size of $60 \mu \mathrm{m}$. We tried to represent in the sampling different types of water bodies: swamps, lakes, ponds, roadside ditches, rice fields, rivers and dams (Fig. 2). Samples were preserved in $10 \%$ formalin and stored in $120 \mathrm{~mL}$ bottles.

We added 21 old samples to our material, previously collected in Vientiane municipality (3 samples), in Pho- hong ( 2 samples), Vangviang (2 samples) and Kasy (2 samples) districts (also Vientiane province) in 1999, and Vientiane municipality in 2004 (12 samples) sampled with a net of the same mesh size and preserved in formalin.

For determination, specimens were selected from samples under a binocular stereoscopic microscope, and studied under a compound optical microscope in a drop of a glycerol-formaldehyde mixture. Few females of each species (if possible) were dissected under a stereoscopic microscope for the study of appendages and postabdomen. Drawings were prepared using a camera lucida attached to a Olympus PM-10AD compound microscope (Olympus, Center Valley, PA, USA), and were made by MS-B and SS.

Some species were prepared for the scanning electron microscopic (SEM) study using the dehydration in a gradual series of alcohol $(60,70,80,90,96$, and $100 \%)$, changing the specimens in each concentration for $10 \mathrm{~min}$, then kept in absolute alcohol for 24-48 $\mathrm{h}$, then critical point dried in the TOUSIMIS chamber, mounted on aluminium stubs, coated with gold, and examined under a scanning electron microscope (JEOL LV-5900 and LEO 1450VP).

We used the computer package EstimateS (Colwell, 1997) to estimate species richness of the Cladocerans in the region. Separate tests were performed for all data, data of 2010-2011, and for rainy and dry seasons of 2010-2011.

\section{RESULTS}

\section{Taxonomical account}

We listed 70 taxa, belonging to 37 genera (Supplementary Tabs. 2-4). Comments on the taxa are represented below.

\section{Order Ctenopoda Sars, 1865}

\section{Family Sididae Baird, 1850}

Diaphanosoma Fischer, 1850. The three species that we identified here (D. dubium, D. excisum and D. sarsi) were expected in this country, as they are very characteristic of the SE Asian plankton (Korovchinsky, 2004, 2013a, 2013b). There were a few cases where we could not determine the exact species, because there were only a few juveniles in the sample. Diaphanosoma excisum and $D$. sarsi are species that are widely distributed in the Old World, while $D$. dubium is tropicopolitan, penetrating the North up to the Amur basin (Korovchinsky, 2004). Ponthalith (2006) also recorded D. voltzi Stingelin, 1905, D. modigliani Richard, 1894 and D. senegal Gauthier, 1951 in the Champasak province of Laos, 1951, but Korovchinsky (2013b), re-studying these samples, confirmed only the latter determination (as D. senegal isanensis Korovchinsky and Sanoamuang, 2008). While D. voltzi can be expected in Laos, considering its presence in neigh- 
bouring Thailand, the occurrence of $D$. modigliani seems to be very dubious (Korovchinsky, 2013b). We also included a Diaphanosoma sp. in Supplementary Tabs. 2-4, which remains unidentified, and does not belong to previous species.

Latonopsis Sars, 1888. Latonopsis australis is a trop- icopolitan, common and widely distributed species in SE Asia. In reality, it consists of a series of cryptic species (Korovchinsky, 2004), therefore the status of the Oriental populations needs to be revised.

Pseudosida Herrick, 1884. Pseudosida szalayi is a typical tropical taxon penetrating East Asia north up to
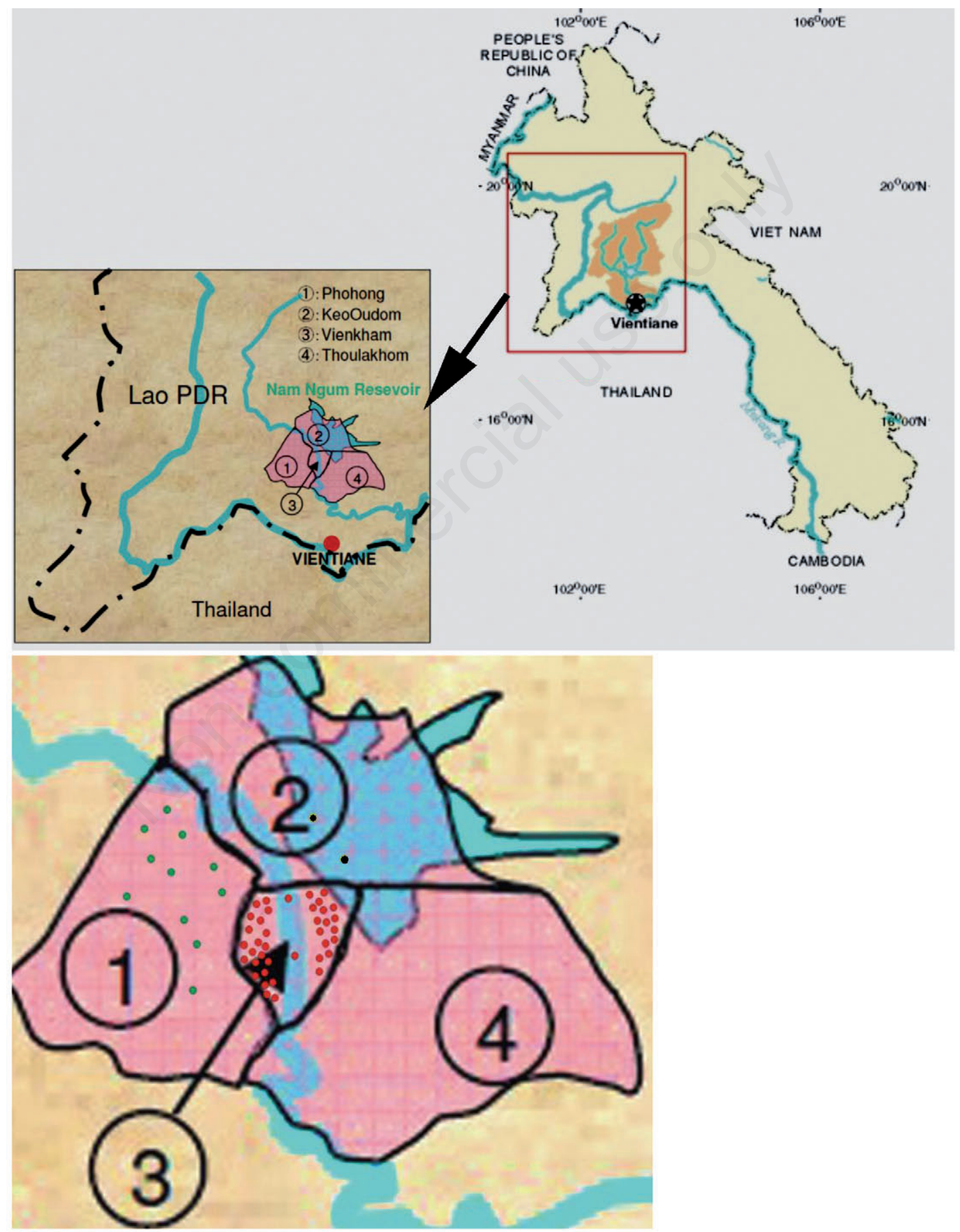

Fig. 1. Laos region where the main 76 samples were collected in 2010-2011: 9 sites in Phonhong district (1); 2 sites in Keo Oudom district (2); 37 sites in Viengkham district (3). 
Korea and the Amur basin (Korovchinsky, 2010; Kotov et al., 2012). It is present in all SE Asian countries (Korovchinsky, 2013a), sometimes misidentified as P. bidentata Herrick, 1888.

\section{Order Anomopoda Sars, 1865}

\section{Family Daphniidae Straus, 1820}

Ceriodaphnia Dana, 1853. Unfortunately, our species determinations (as most identifications of tropical Ceriodaphnia) can be regarded as preliminary, as the taxonomy of this genus is in a poor state. In particular with relation to C. reticulata and C. laticaudata (Kořínek, 2002), there are some difficulties. Korovchinsky (2013a) correctly concluded that there is not a single well-revised species of $\mathrm{Ce}$ riodaphnia in SE Asia. Ceriodaphnia cf. cornuta is a very common and widely distributed tropical-subtropical animal, however it is apparently a species group with significant (or complete) continental endemism (Berner, 1985; Elías-Gutiérrez et al., 2008a; Sharma and Kotov, 2013).

Daphnia O. F. Müller, 1785. We found only $D$. lumholtzi in Laos, which is also present in the surrounding countries. It is a tropical species of the Old World, aggressively occupying the New World (Havel and Hebert, 1993; Benzie, 2005). The taxon was described from Australia, and there is evidence that there are several species in this complex (Korrínek, 2002), an interesting question that could be addressed to in the future.

Scapholeberis Schödler, 1858. Only a single species, S. kingi was found, which is very common in East Asia, penetrating north up to Korea and the Amur basin (Kotov et al., 2011, 2012).

Simocephalus Schödler, 1858. Among three species, S. heilonjangensis seems to be distributed in South Asia and Australia (Orlova-Bienkowskaja, 2001), while two others belong to widely distributed groups and need to be revised worldwide. Korovchinsky (2013a) listed also $S$. mixtus Sars, 1903 and S. acutirostratus (King, 1853) among the good SE Asian species, but we did not encounter them in our samples.

\section{Family Moinidae Goulden, 1968}

Moina Baird, 1850. The two species revealed here belong to widely distributed groups that need to be revised. Moina dubia was regarded by Smirnov (1976) as a subspecies of M. micrura. Indeed, M. dubia belongs to the M. micrura species group, and the tropical populations of the Old World normally bear somewhat larger teeth in the proximal pecten on the postabdominal claw when compared with the distal pecten, a diagnostic character. In reality, both species groups need to be revised worldwide.

Moinodaphnia Herrick, 1887. The genus is regarded as monotypical, although it is widely distributed in the tropics and subtropics of the Old and New World
(Goulden, 1968), penetrating into non-tropical areas of Asia up to Korea (Kotov et al., 2012). The genus needs to be revised worldwide.

\section{Family Ilyocryptidae Smirnov, 1976 sensu Smirnov, 1992}

Ilyocryptus Sars, 1862. The two species revealed here are distributed in a very different manner. Ilyocryptus spinifer is a very characteristic and widely distributed tropicopolitan species (Kotov and Dumont, 2000) penetrating even very isolated archipelagoes (Schabetsberger et al., 2009) and reaching the Amur basin and Korea (Kotov et al., 2011, 2012) in the north. In contrast, I. thailandensis was previously known only from two close localities in North Thailand (Kotov and Sanoamuang, 2004b). Now we found the latter species in two localities about $300 \mathrm{~km}$ North East from the type locality and can say with confidence that i) this species is very rare and ii) it is more widely distributed in SE Asia than previously thought (with the initial information from the first description only).

\section{Family Macrothricidae Norman \& Brady, 1867}

Grimaldina Richard, 1892. A monotypical genus, distributed in the tropics of Old and New World (Smirnov, 1976), originally described from D. R. Congo, Africa. It likely consists of a series of cryptic species but the SE Asian populations remain unrevised (H.J. Dumont, personal communication; Maiphae et al., 2008).

Macrothrix Baird, 1843. We found four species, very characteristic for SE Asia. Macrothrix odiosa and M. triserialis are distributed in tropical and subtropical regions of Africa and Asia, including SE Asia (Dumont et al., 2002; Kotov et al., 2005). While M. odiosa reaches Central Asia and even Armenia in the north, its penetration to the north is not so extensive in East Asia. In contrast, $M$. triserialis is present in Korea (Kotov et al., 2012). Korovchinsky (2013a) places M. flabelligera Smirnov 1992 in the list of good species, but apparently these populations in SE Asia (not in Australia) belong to a special morphotype of $M$. triserialis, having additional spine-like setules on the segments of antenna II, in analogy with the South American M. elegans Sars, 1901 (Kotov et al., 2004). Macrothrix vietnamensis seems to be an endemic of the Oriental region. It was earlier misidentified as the Palaearctic M. laticornis (Jurine, 1820) (Silva-Briano et al., 1999). Macrothrix spinosa is a very common circumtropical taxon (Smirnov, 1976), occurring in isolated archipelagoes (Schabetsberger et al., 2009) and likely forming a group of cryptic species.

\section{Family Bosminidae Baird, 1845 sensu Sars, 1865}

Bosmina Baird, 1845. Only a single taxon of the sub- 

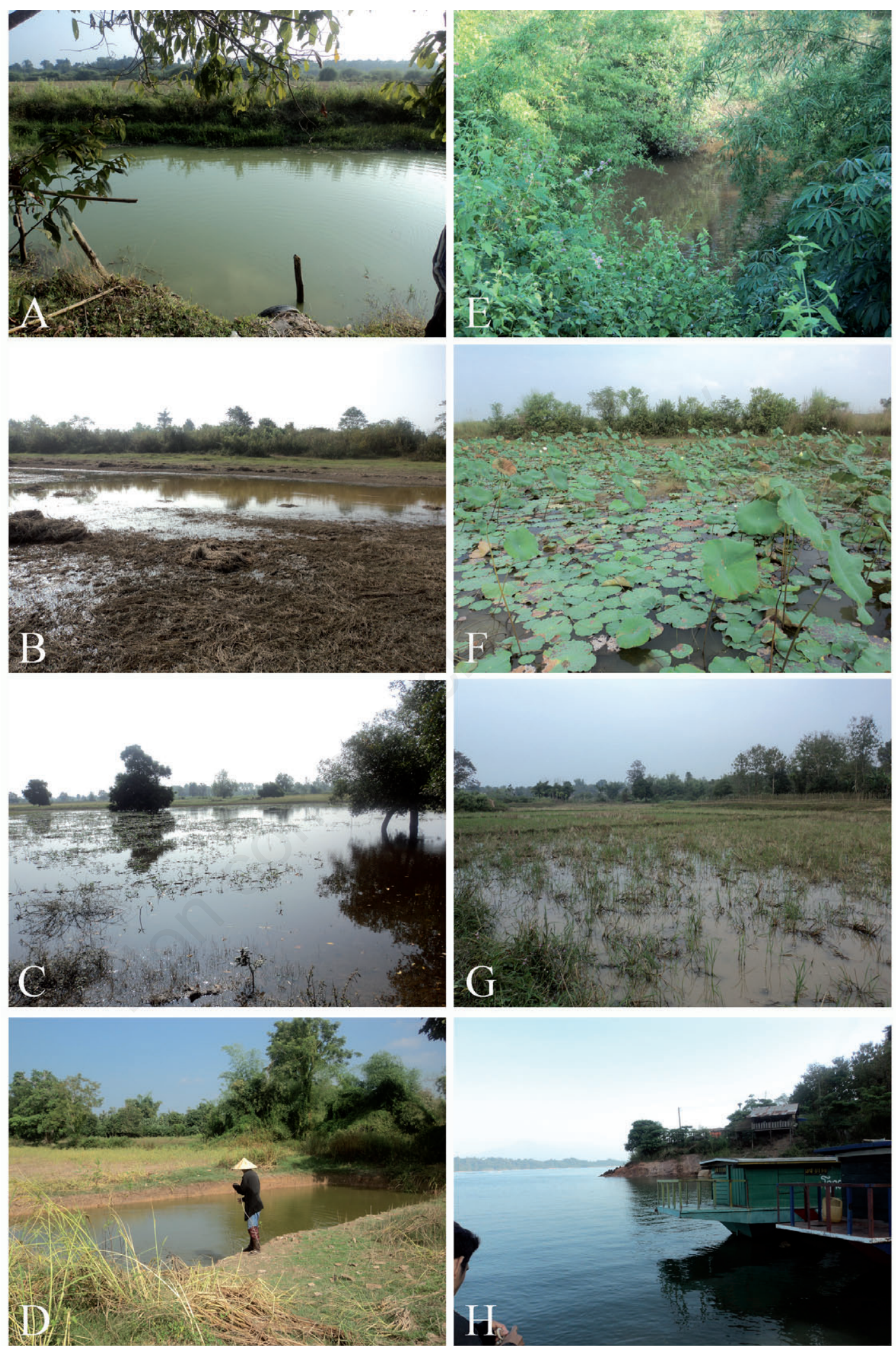

Fig. 2. Different types of water bodies in Laos that were sampled during this study (dry season). A) Locality VTP01 - Nong Youp pond; B) locality VTP08 - Thaphoxay swamp 1; C) locality VTP11 - Phonekang South, pond; D) locality VTP14 - Nong Nork pond; E) locality 17 - Chenglong pond; F) locality 27 - Padook pond; G) locality 30 - North Napho rice field; H) locality 47 - Num Ngum dam 1. 
genus Bosmina (Liederobosmina) Brtek, 1997 was found. It is traditionally determined as B. meridionalis (mainly present in Australia), although this is very superficial, considering the obvious problems in identifying liederobosminid females. Males are more informative (Kotov et al., 2009), but they were never described for SE Asian populations. Only a global revision of the subgenus would make the identification of Asian liederobosminids more precise. Bosmina cf. longirostris (O. F. Müller, 1785) is recorded for other SE Asian countries (Korovchinsky, 2013a), and the same is true for B. (Sinobosmina) fatalis Burckhardt, 1924 (e.g. Maiphae et al., 2008), but we did not find these species in Laos.

Bosminopsis Richard, 1895. Bosminopsis deitersi is a tropicopolitan taxon, very common in tropics-subtropics of the Old and New World, yet penetrating north, even up to the Polar ring (Pirozhnikov, 1937). Preliminary molecular data suggest that this is a complex of species with a more restricted distribution, conforming to the non-cosmopolitanism concept (Frey, 1982a).

\section{Family Chydoridae Dybowski \& Grochowski, 1894 emend. Frey 1967}

\section{Subfamily Aloninae Dybowski \& Grochowski, 1894 emend. Frey, 1967}

\section{Acroperus Baird, 1843}

Acroperus cf. harpae (Baird, 1834). Representatives of the genus Acroperus are relatively rare in the tropics. Populations of the A. harpae-habitus are known from many regions, including some SE Asian countries (Korovchinsky, 2013a), but such populations need to be assessed as part of a worldwide revision. The presence of A. harpae s.str. in tropical regions is doubtful (Chatterjee et al., 2013), yet according to Sinev (2009), the populations of neighbouring Thailand are phenotypically identical to the Palaearctic species.

\section{Alona Baird, 1843}

Alona cf. affinis Leydig, 1860. (Fig. 4A-C). Described from the Palaearctic, worldwide records of $A$. affinis in fact belong to a number of species, but the Oriental populations remain unrevised. Sinev (1997) evaluated the Australian populations, describing a number of new species (e.g. A. elliptica Sinev, 1997; Van Damme et al., 2011); still, SE Asian populations should be compared with both Palaearctic and Australian species in detail since SE Asian forms can represent other taxa. The Laos specimens do belong to the $A$. affinis complex, but the limb morphology remains to be analysed. Notes on the SE Asian populations shown in Maiphae's $\mathrm{PhD}$ thesis (2005), suggest that this is not $A$. affinis sensu stricto, but a revision is necessary.
Alona cambouei de Guerne \& Richard, 1893 (Fig. 5). This is a species originally described from Madagascar (de Guerne \& Richard, 1893), but with a wide distribution in Africa and Asia (Sinev, 2001). It is very close to A. pulchella, which is an Australian species, but $A$. cambouei has disconnected head pores (Sinev, 2001). Both are on record in SE Asia yet A. pulchella and A. cambouei are often mentioned and also often confused (e.g. Maiphae et al., 2008; Korovchinsky, 2013a). In fact, it remains to be sorted out in detail whether the SE Asian A. cambouei is truly identical to the populations from Madagascar.

Alona cf. costata Sars, 1862 (Fig. 4D-G). Species complex, with $A$. costata - a Palaearctic species (Sinev, 2008) -, yet with a number of siblings worldwide. Records in SE Asia need to be revised, but the SE boundary of the distribution of genuine $A$. costata is unknown. In southern China, it seems that real $A$. costata is present (Van Damme, personal observation). Close, similar species in the Australasian region, such as $A$. setigera or $A$. cheni (Sinev, 1999), could be confused with A. costata. However, Laotian populations are closer to $A$. costata (yet not necessarily conspecific) instead of showing affinities to A. setigera or A. cheni.

Alona cf. guttata Sars, 1862 (Fig. 4H-J). Originally a Palaearctic species, and populations outside the region should be revised (Van Damme and Dumont, 2008a). In SE Asia, this should be done especially in comparison to Alona clathrata Sars, 1888, which is the yet unrevised Australian member of the A. guttata species complex, as well as in comparison to the real A. guttata from the Palaearctic.

Alona kotovi Sinev, 2012. Described from Vietnam as the SE Asian sibling species of $A$. quadrangularis (O. F. Müller, 1776); most $A$. quadrangularis records from the region likely refer to $A$. kotovi, yet these populations need to be revised in detail and compared to both A. quadrangularis s. str., which is a Palaearctic species (Van Damme and Dumont, 2008a) and A. kotovi, its SE Asian sibling (Sinev, 2012).

Alona sarasinorum Stingelin, 1900. A peculiar euryhaline species that is endemic to the Oriental region and only sporadically mentioned from the neighbouring areas (e.g. Thailand: Maiphae et al., 2008). The taxon is revised in a separate study in this special volume (Van Damme and Maiphae, 2013).

Alona siamensis Sinev \& Sanoamuang, 2007. A species described from Thailand to replace the SE Asian records of Alona dentifera (Sars, 1901) (Sinev and Sanoamuang, 2007); it is actually a Coronatella (Van Damme and Dumont, 2008a), but the species still needs to be formally removed from Alona. It is a species that can be expected in Laos, as it occurs in the neighbouring countries, and the former Oriental records of $A$. dentifera now refer to $A$. siamensis. 

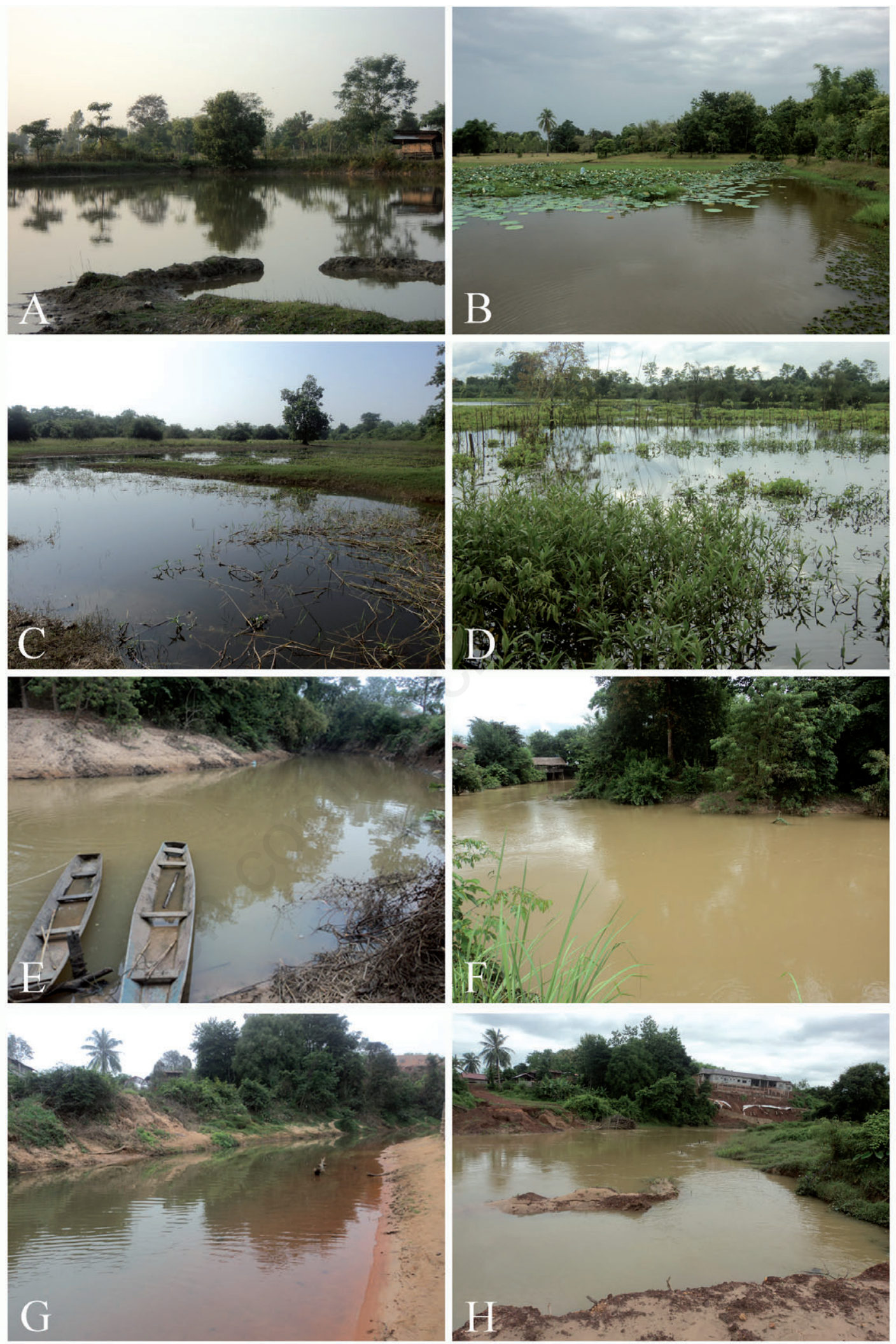

Fig. 3. Differences between some localities in Laos during the dry (left) and wet (right) season. A,B) Locality VTP05 - Nong Khouy Lake 1; C,D) locality VTP21 - Nong Someseng swamp; E,F) locality VTP43 - South Napho river; G,H) locality VTP44 - Nam Cheng river. 


\section{Anthalona Van Damme, Sinev \& Dumont, 2011}

Anthalona harti harti Van Damme, Sinev \& Dumont, 2011 (Figs. 4K, 4L and 6) This species was originally described from South Africa and it was supposed that distribution most likely extends to East Africa and Mediterranean (Van Damme et al., 2011). Shortly after,
A. harti was also found in SE Asia: Thailand, Vietnam and Cambodia (Sinev and Kotov, 2012; Van Damme et al., 2013). The species seems to be widely distributed, common in the tropics and subtropics of Africa and Asia. In Indochina, $A$. harti is the most common species of the genus (Sinev and Kotov, 2012). At the same time, earlier
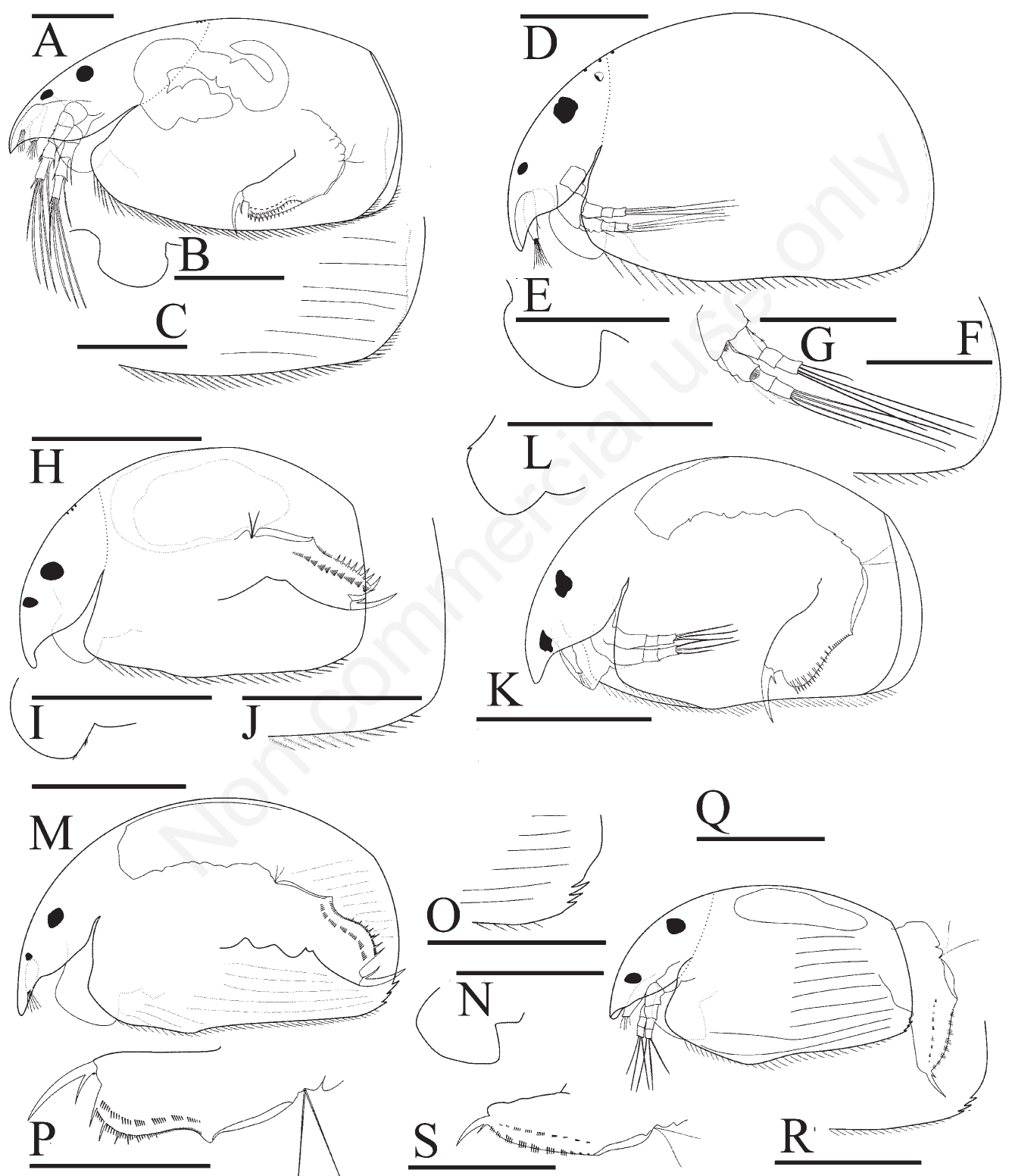

Fig. 4. Aloninae from Vientiane province, Laos. A-C) Alona cf. affinis from Nam Cheng in Napho village, adult in general view, labrum and postero-ventral valve portion; D-G) Alona cf. costata from Hongkang (South Napho village), adult in general view; labral keel, postero-ventral valve portion and antenna II; H-J) Alona cf. guttata from Nong Samkha in Viengkham district, lateral view of adult, labral keel and postero-ventral portion of valve; K-L) Anthalona harti from Houyphai (roadside channel) in Viengkham district, adult in general view and labral keel; M-P) Coronatella cf. monacantha from Nam Ngum dam, adult female in general view, labral keel, postabdomen and postero-ventral portion of valve; Q-S) Coronatella $\mathrm{cf}$. monacantha from rice field at Phonehong village, adult male, labral keel, postero-ventral valve portion and postabdomen. Scale bars: $0.1 \mathrm{~mm}$. 
determinations of $A$. verrucosa (Sars, 1901) from SE Asia can be regarded as misidentifications.

Anthalona sanoamuangae Sinev and Kotov, 2012. Described from the Mekong river basin in Thailand and South Vietnam (Sinev and Kotov, 2012). The presence of this rare SE Asian species in Laos was expected. At this moment, the taxon seems to be restricted to the Indochina peninsula.

\section{Camptocercus Baird, 1843}

Camptocercus vietnamensis Thanh, 1980. This species was previously known from North and South Vietnam
(Thanh et al., 1980; Sinev, 2011), yet it was later shown to have a wider distribution in East Asia, occuring up to South Korea (Kotov et al., 2012). Previous records of $C$. australis Sars, 1896 and C. uncinatus Smirnov, 1971 (Korovchinsky, 2013a) in SE Asia can be at least partially attributed to this species.

\section{Celsinotum Frey, 1991}

Celsinotum macronyx (Daday, 1898). It is the only Oriental species in this predominantly Australian genus. Celsinotum macronyx was originally described from Sri
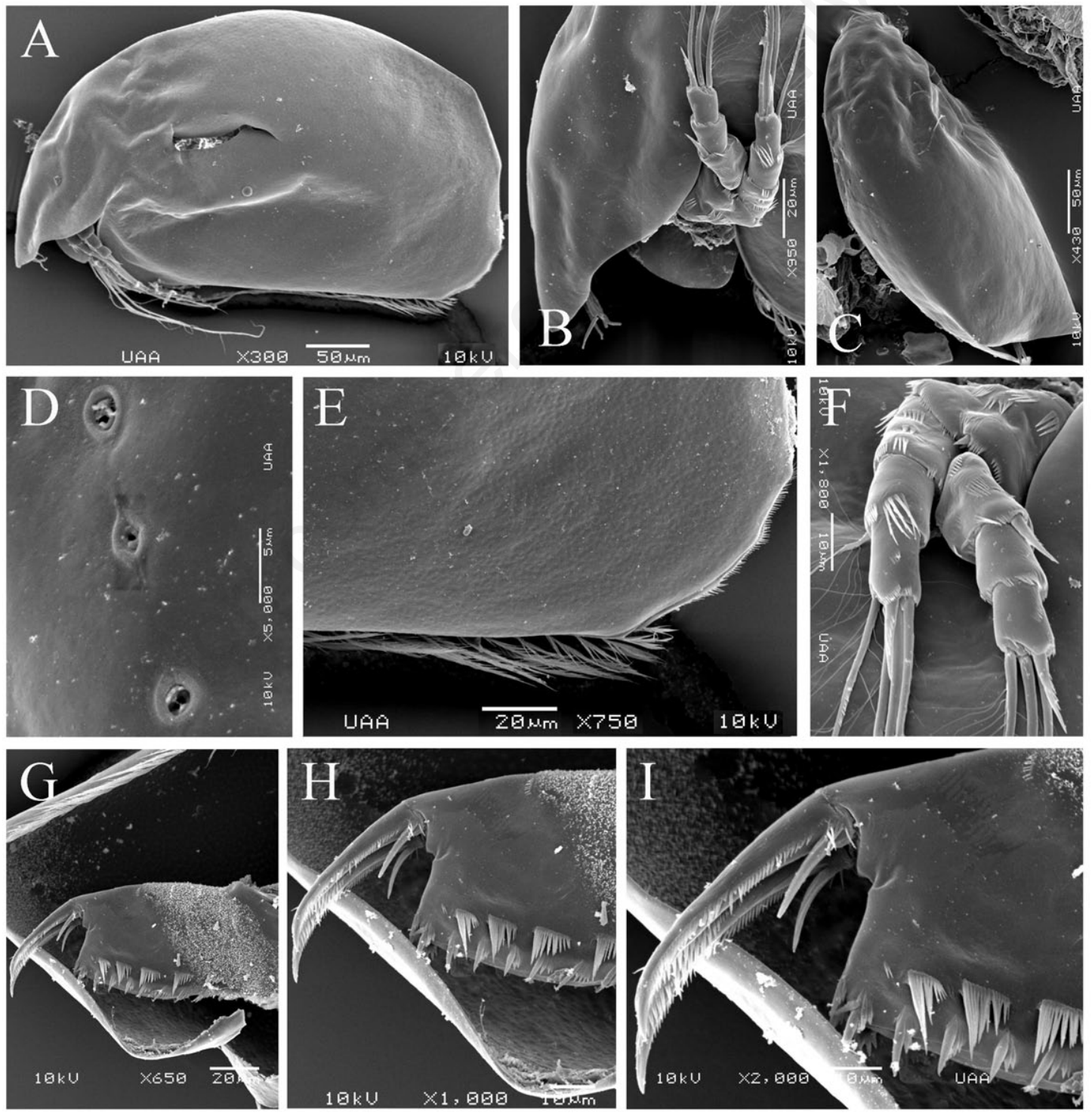

Fig. 5. Scanning electron microscopy of Alona cambouei, parthenogenetic female from LV09 - Ban Hua Chang roadside canal, Vientiane municipality, Laos. A) General view; B) head, lateral view; C) dorsal view; D) head pores; E) postero-ventral valve portion; F) antenna II; G-I) postabdomen. 
Lanka and allocated to the genus Alona (Daday, 1898), subsequently placed in Indialona (Smirnov, 1971), then returned to Alona (Rajapaksa and Fernando, 1985, 1987a), and now moved to Celsinotum (Sinev and Kotov, 2012). It occurs in the surrounding regions, yet it is not common (Sinev and Kotov, 2012; Van Damme et al., 2013).

\section{Coronatella Dybowski \& Grochowski, 1894}

Coronatella cf. monacantha (Sars, 1901) (Fig. 4M-S). It was described from South America (Sars, 1901), and placed in the genus Alona, and then moved to Coronatella (Van Damme and Dumont, 2008a). Coronatella monacantha s.str. most likely is an exclusively Neotropical taxon. Some authors (Sinev, 2004; Van Damme et al., 2010, 2013) have suggested that the SE Asian $C$. cf. monacantha likely is C. acuticostata (Sars, 1903), the taxonomic status of which should be clarified in future revisions.

Coronatella $\mathrm{cf}$. rectangula (Sars, 1862). The rectangula-like populations need to be revised worldwide, as this is one of the most complex taxa in the Aloninae (Van Damme and Dumont, 2008b; Van Damme et al., 2010).

Coronatella sp. (Fig. 7A and 7B). This is an undescribed species, but we only had a single specimen, insufficient for adequate description. The Laotian specimen is identical to Coronatella sp. in Sinev and Kotov (2012).

\section{Euryalona Sars, 1901}

Euryalona orientalis (Daday, 1898) (Figs. 7C-G and
8). It is a very characteristic circumtropical genus and species, which needs to be revised worldwide. Euryalona orientalis is common in the SE Asian countries (Rajapaksa and Fernando, 1987b; Korovchinsky, 2013a). The morphology of $E$. orientalis is now discussed by Van Damme and Maiphae (2013), who suggest that it likely is a species complex.

\section{Karualona Dumont \& Silva-Briano, 2000}

Karualona cf. iberica (Alonso \& Pretus, 1989). Apparently, some populations of Karualona resemble $K$. iberica, which was originally described from Spain (Alonso and Pretus, 1989) and then also recorded in SE Asia (Maiphae et al., 2005, 2008; Van Damme et al., 2013). It could be either a species widely distributed in the tropics-subtropics of Asia, or just confused with $K$. cf. karua (see below) (Van Damme et al., 2013),

Karualona cf. karua (King, 1853) (Figs. 7H-L, 9 and 10). Karualona karua is a very common tropical-subtropical species originally described from Australia (King, 1853), but it probably consists of a series of cryptic species; Van Damme et al. (2013) illustrated different morphotypes in South Thailand. We also found at least two morphotypes, which could be different species. The two morphotypes differ in: i) shape and distance of the teeth on the postero-ventral valve margin [thin and spacely located (Fig. 9F) vs thick and closely located (Fig. $10 \mathrm{C})$ ]; ii) shape of the distal margin of the postabdomen
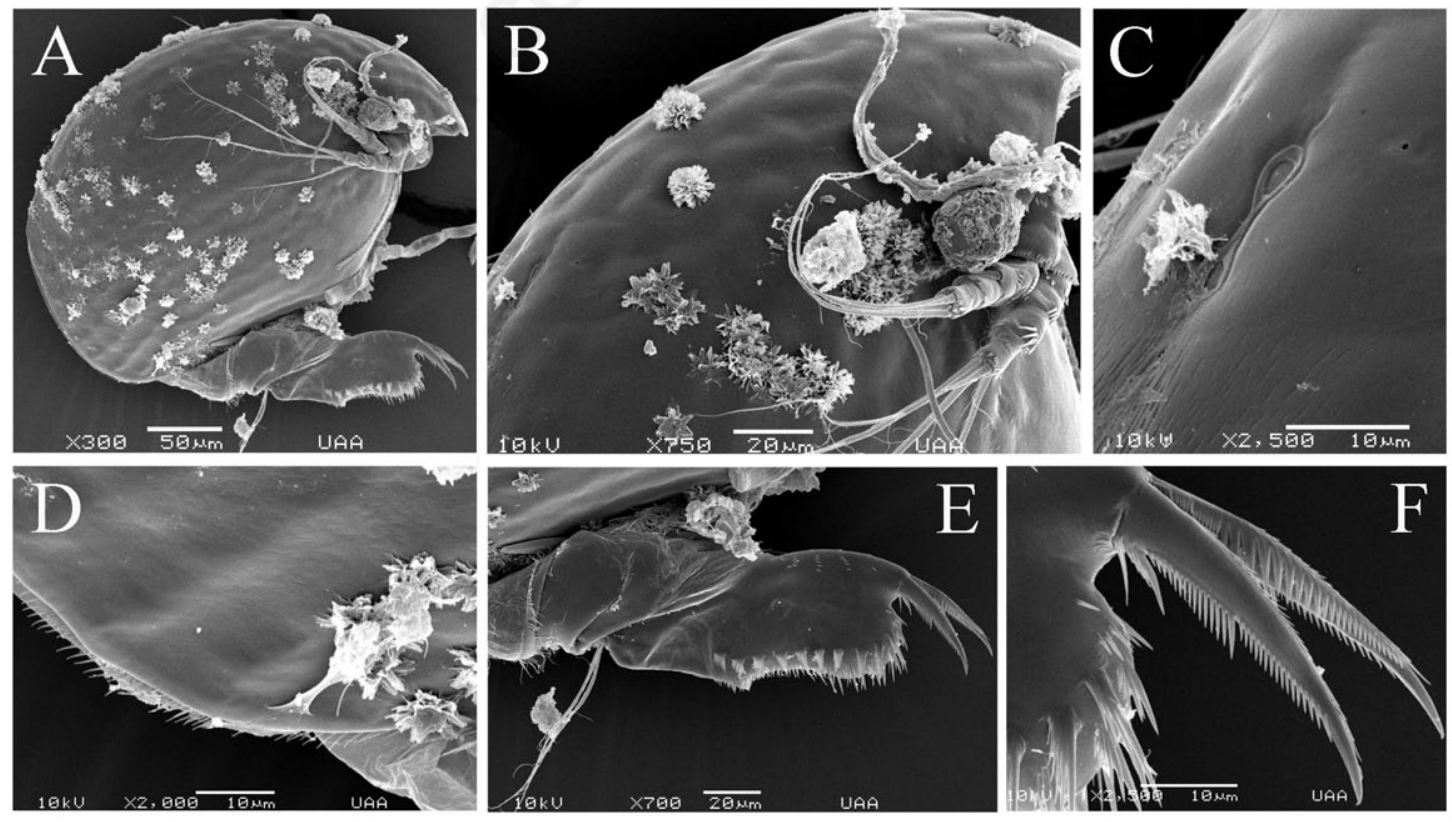

Fig. 6. Scanning electron microscopy of Anthalona harti, parthenogenetic female from VP3.1 - Ban Phang Hang fish pond, Vientiane province, Laos. A) General view; B) head; C) head pores; D) postero-ventral valve portion; E,F) postabdomen. 
[convex (Fig. 9G) vs almost straight (Fig. 10E)]; iii) length of denticles on the branches of antenna II [short (Fig. 9B) $v s$ long (Fig. 10D)]. These observations confirm the suggestion by Van Damme et al. (2013) that the karuagroup in SE Asia needs to be revised.

Karualona $\mathrm{cf}$. kwangsiensis Jiang, 1963. Few populations from Laos belong to $K$. kwangsiensis, described from China (Jiang, 1963) and then found in India (Venkataraman, 1999). This is a taxon recognisable by the denticles on the postero-ventral portion of the valve, which are projected downwards instead of being directed posterior, as opposed to the typical K. karua. It could be a separate taxon or a morphotype of $K$. karua, and needs to be revised (Van Damme et al., 2013). In any case, it is

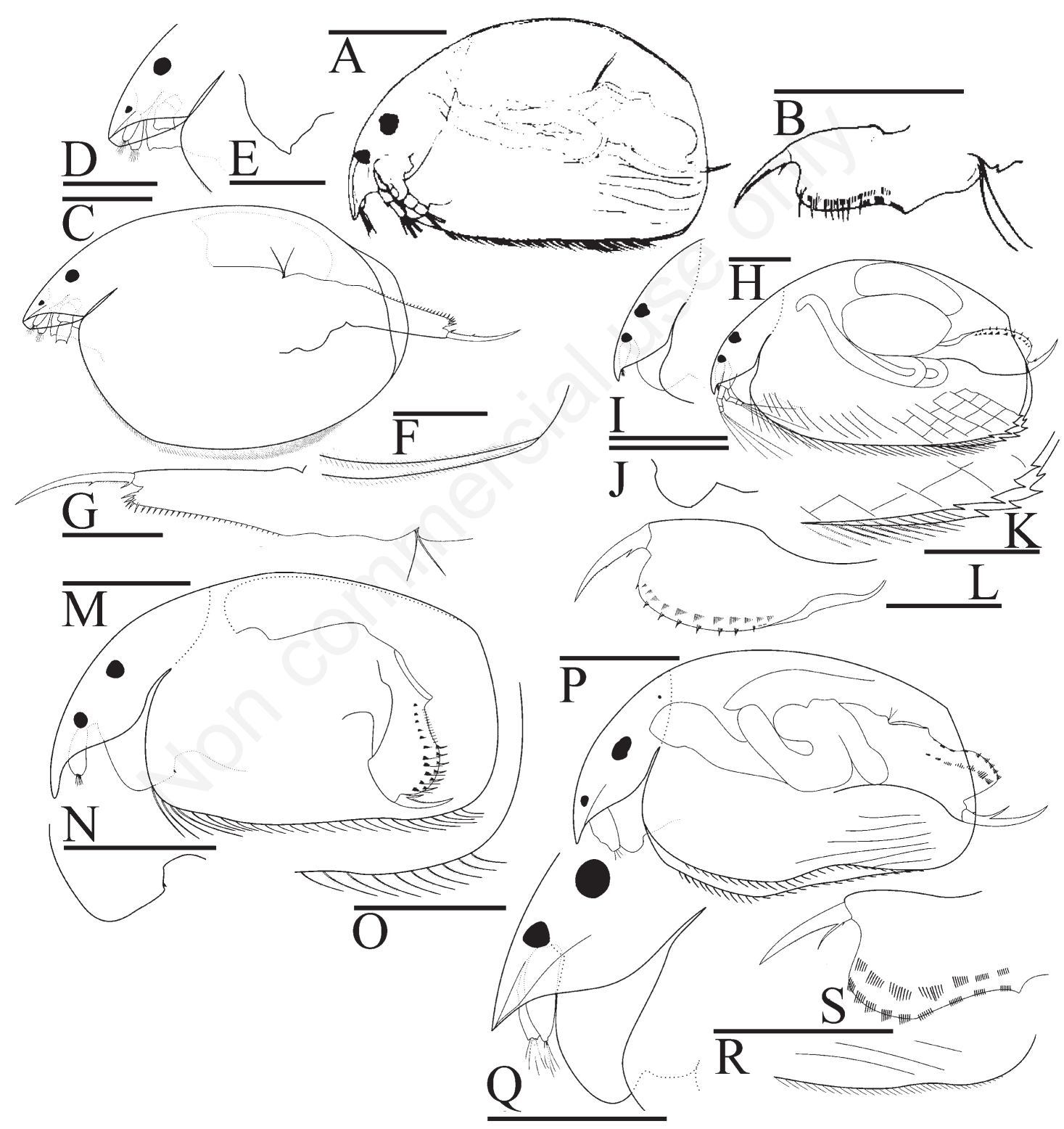

Fig. 7. Aloninae from Vientiane province, Laos. A,B) Coronatella sp. from Ban Hui Sawn rice field, general view, head and postabdomen; C-G) Euryalona orientalis from Nong Thongpane, adult in general view, its head, labrum, postero-ventral portion of valves and postabdomen; H-L) Karualona cf. karua from Nam Cheng (Napho village), adult in general view, its head, labral keel, posteroventral portion of valve and postabdomen; M-O) Matralona freyi from Nam Ngum dam 1, adult in general view, labral keel and postero-ventral portion of valve; P-S) Nicsmirnovius eximius from Nam Ngum1 (Donekeud), adult in general view, its head, postero-ventral portion of valve and postabdomen. Scale bars: $0.1 \mathrm{~mm}$. 

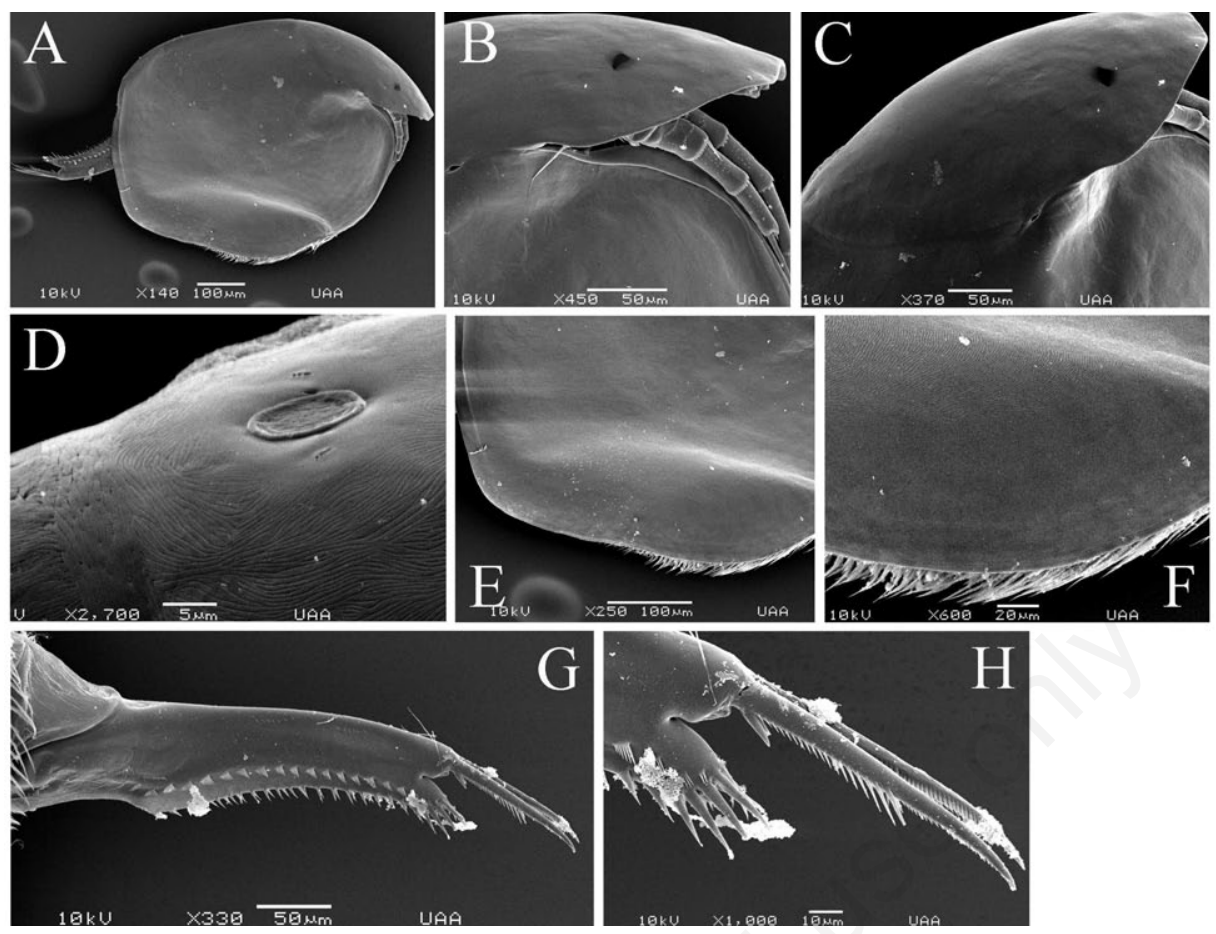

Fig. 8. Scanning electron microscopy of Euryalona orientalis, parthenogenetic female from LV11 - Hui Sawn swamp 2, Vientiane municipality, Laos. A) General view; B,C) head; D) head pores; E) postero-ventral valve portion; F) antero-ventral valve portion; G,H) postabdomen.
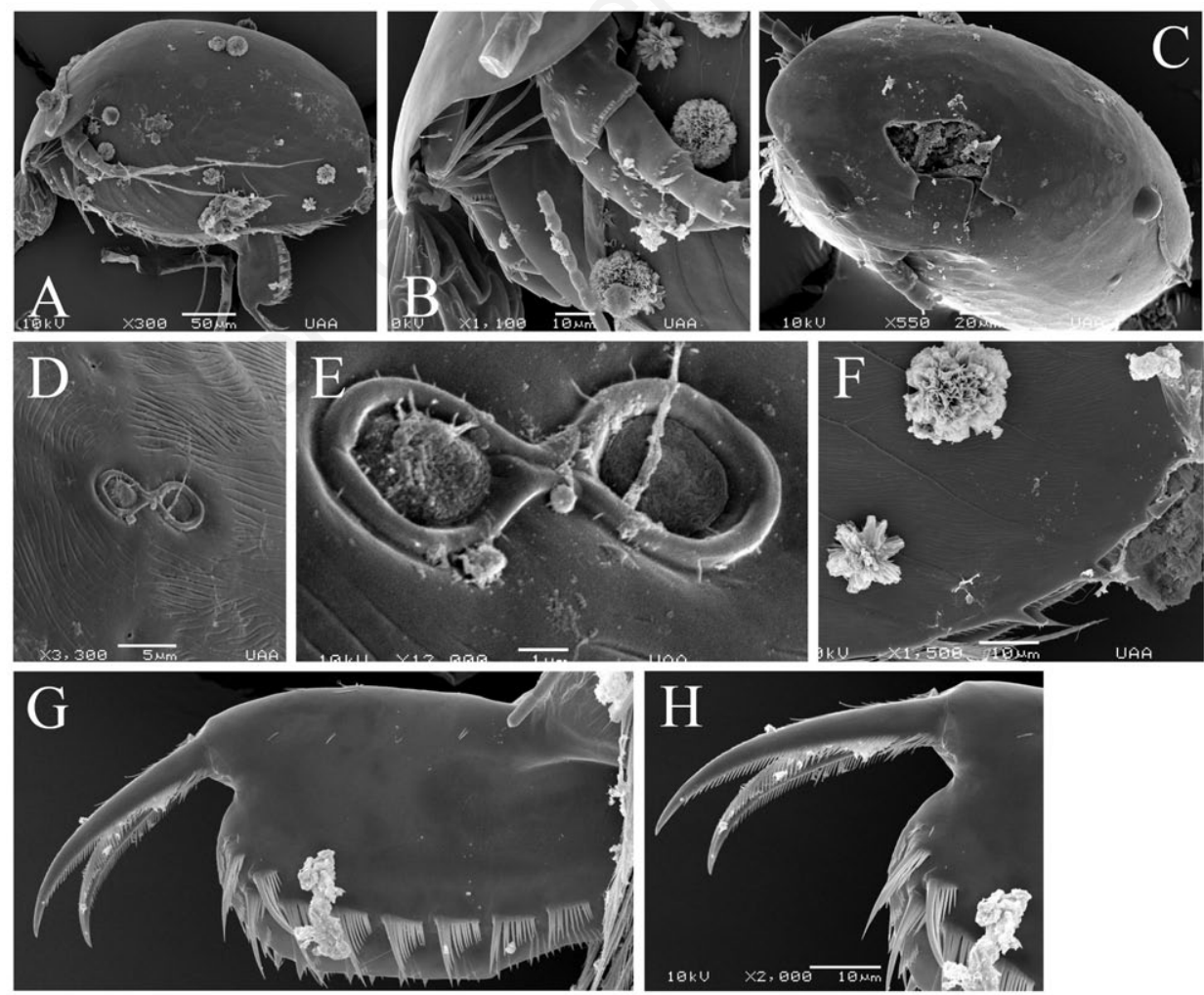

Fig. 9. Scanning electron microscopy of Karualona cf. karua, morphotype 1, parthenogenetic female from LV03 - Nong Suem lotus pond, Vientiane municipality, Laos. A) General view; B) head; C) dorsal view; D,E) head pores; F) postero-ventral valve portion; G,H) postabdomen. 
clear that the taxonomy of SE Asian Karualona is more complex (Van Damme et al., 2013).

Karualona sp. nov. This animal is described by Van Damme et al. (2013) and recorded by Sinev and Korovchinsky $(2013 a, 2013 b)$ in this volume, a new species for the region.

\section{Kurzia Dybowski \& Grochowski, 1894}

Kurzia brevilabris Rajapaksa \& Fernando, 1986. Common species in SE Asia (Rajapaksa and Fernando, 1986) and its presence in Laos was expected.

Kurzia longirostris (Daday, 1898) is an even wider distributed tropicopolitan species of the Old World (Rajapaksa and Fernando, 1986) and the New World (Elías-Gutiérrez et al., 2006, 2008b). In East Asia, it occurs as far north as South Korea (Kotov et al., 2012). Kurzia longirostris is recorded for all SE Asian countries (Korovchinsky, 2013a), and up to now there are no indications of the existence of a cryptic species complex (in the Old World).

\section{Leberis Smirnov, 1989}

Leberis diaphanus (King, 1853) (Fig. 11). The species was described from Australia as Alona by King (1853) and then transferred to the genus Leberis (Sinev et al., 2005). Males in SE Asia were described by Sinev and Sanoamuang (2011). It is very common in the tropics-sub- tropics of the Old World. The taxon could be regarded as tropicopolitan, reaching Korea in the north of its distribution (Yoon, 2010).

Leberis sp. Besides the more common L. diaphanus, we found specimens that cannot be attributed to the latter, but seem closer to the Neotropical L. davidi or a yet undescribed species. We prefer to keep this record here as L. sp., because there are also still unrevised Leberis species in the region that can be valid. For example, Daday (1898) described a Leberis from Sri Lanka (as Alonella punctata) which has never been formally re-evaluated. In any case, it seems to us that there is more than one Leberis species in the region.

\section{Leydigia Kurz, 1875}

Leydigia ciliata Gauthier, 1939. Described from Africa (Gauthier, 1939) and then found to be tropicopolitan (Smirnov, 1971; Kotov et al., 2003, 2012; Kotov, 2009). Sinev and Sanoamuang (2011) found some differences between the males from SE Asia and those from Africa, which could suggest a specific status of the Oriental populations (species or subspecies). Analysis of the descriptions and re-examination of the available material have not confirmed the occurrence of any other species of Leydigia in SE Asia. Therefore, L. ciliata seems to be the only Leydigia known so far from the region.
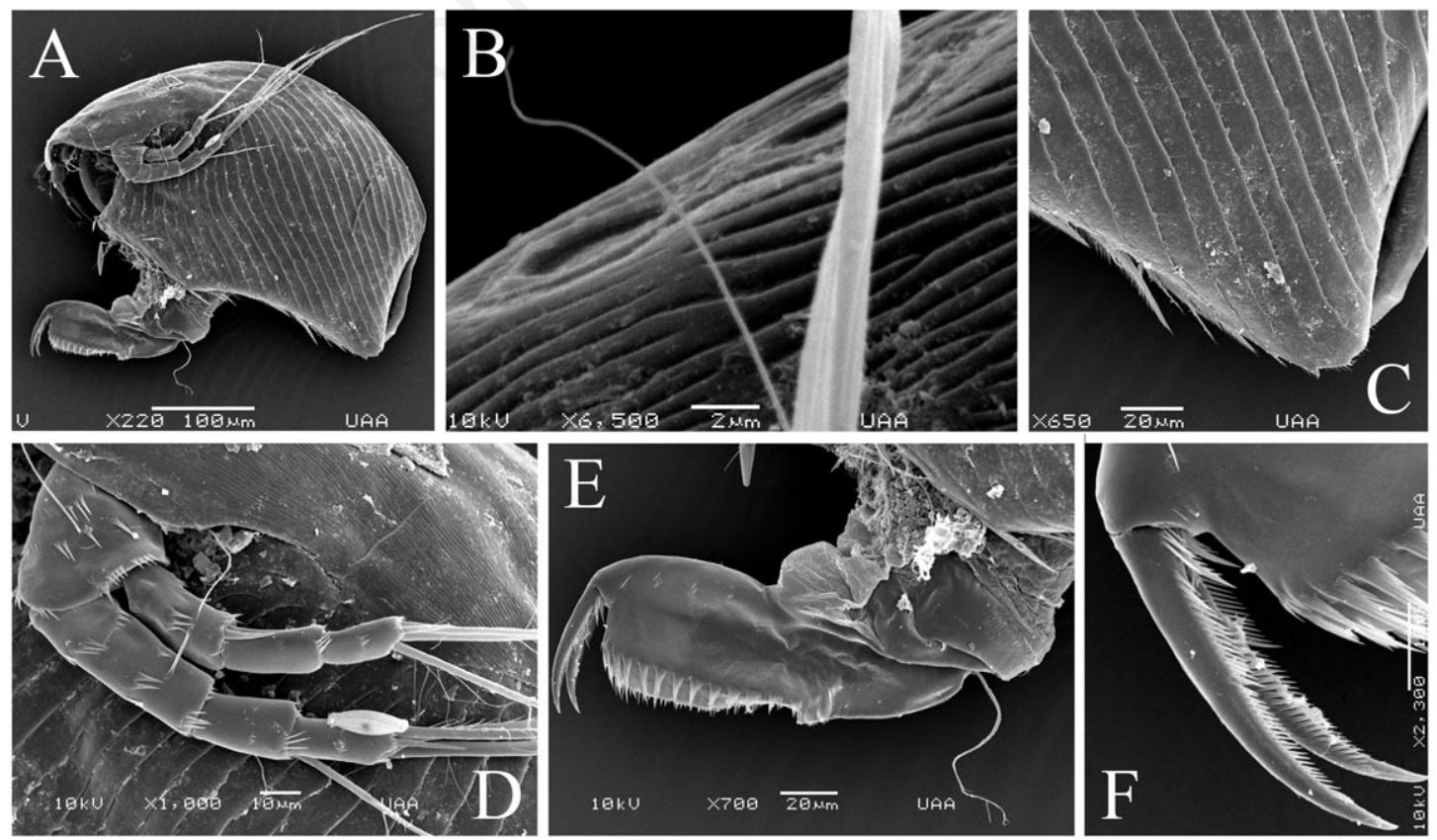

Fig. 10. Scanning electron microscopy of Karualona cf. karua, morphotype 2, parthenogenetic female from VM1.1 - Ban Phang Hang, Vientiane municipality, Laos. A) General view; B) head pores; C) postero-ventral valve portion; D) antenna II; E,F) postabdomen and postabdominal claws. 


\section{Leydigiopsis Sars, 1901}

Leydigiopsis sp. This is apparently a new taxon, rare yet occuring in different countries of the Oriental region (Sanoamuang, 1998; Maiphae et al., 2005; Tanaka and Ohtaka, 2010; Van Damme et al., 2013). The species is described by Van Damme and Sinev (2013).

\section{Matralona Van Damme \& Dumont, 2009}

Matralona freyi Idris \& Fernando, 1981 (Fig. 7M-O). This taxon was originally described as Alona from West Malaysia (Idris and Fernando, 1981; Idris, 1983) and then suggested as belonging to Matralona by Van Damme and Dumont (2009), to which it was subsequently translocated (Sinev and Kotov, 2012). To date this species was known from Malaysia only (Sinev and Kotov, 2012), our finding is the first record outside of Malaysia. The species seems to be very rare and endemic to SE Asia.

\section{Nicsmirnovius Chiambeng \& Dumont, 1999}

Nicsmirnovius eximius (Kiser, 1948) (Figs. 7P-S and 12A-E). Described from the Pearl river in SE China (Kiser, 1948) as Alona and then translocated to the genus Nicsmirnovius (Van Damme et al., 2003). There is a single species in the Oriental zone, $N$. eximius, which occurs in different SE Asian (Idris, 1983; Kotov and Sanoamuang, 2004a; Tanaka and Ohtaka, 2010; Van Damme et al., 2013; Korovchinsky, 2013a) and South Asian countries (Chatterjee et al., 2013), but being a rheophilic species it is not very common in littoral sam-
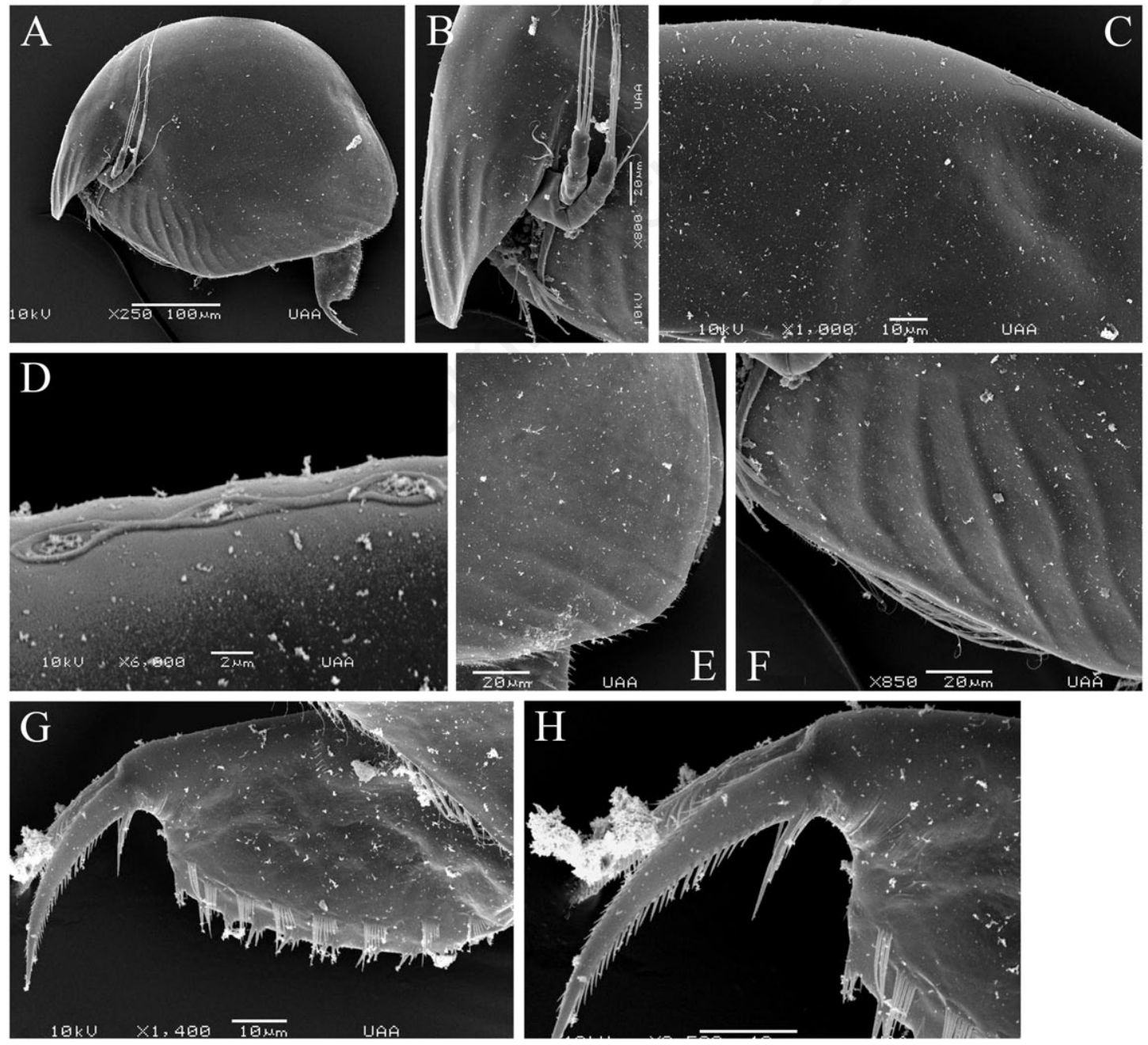

Fig. 11. Scanning electron microscopy of Leberis diaphanus, parthenogenetic female from VM1.1. - Ban Phang Hang, Vientiane municipality, Laos. A) General view; B) head, lateral view; C) dorsum, region of head pores; D) head pores; E) postero-ventral valve portion; F) antero-ventral valve portion; $\mathrm{G}, \mathrm{H})$ postabdomen and postabdominal claws. 

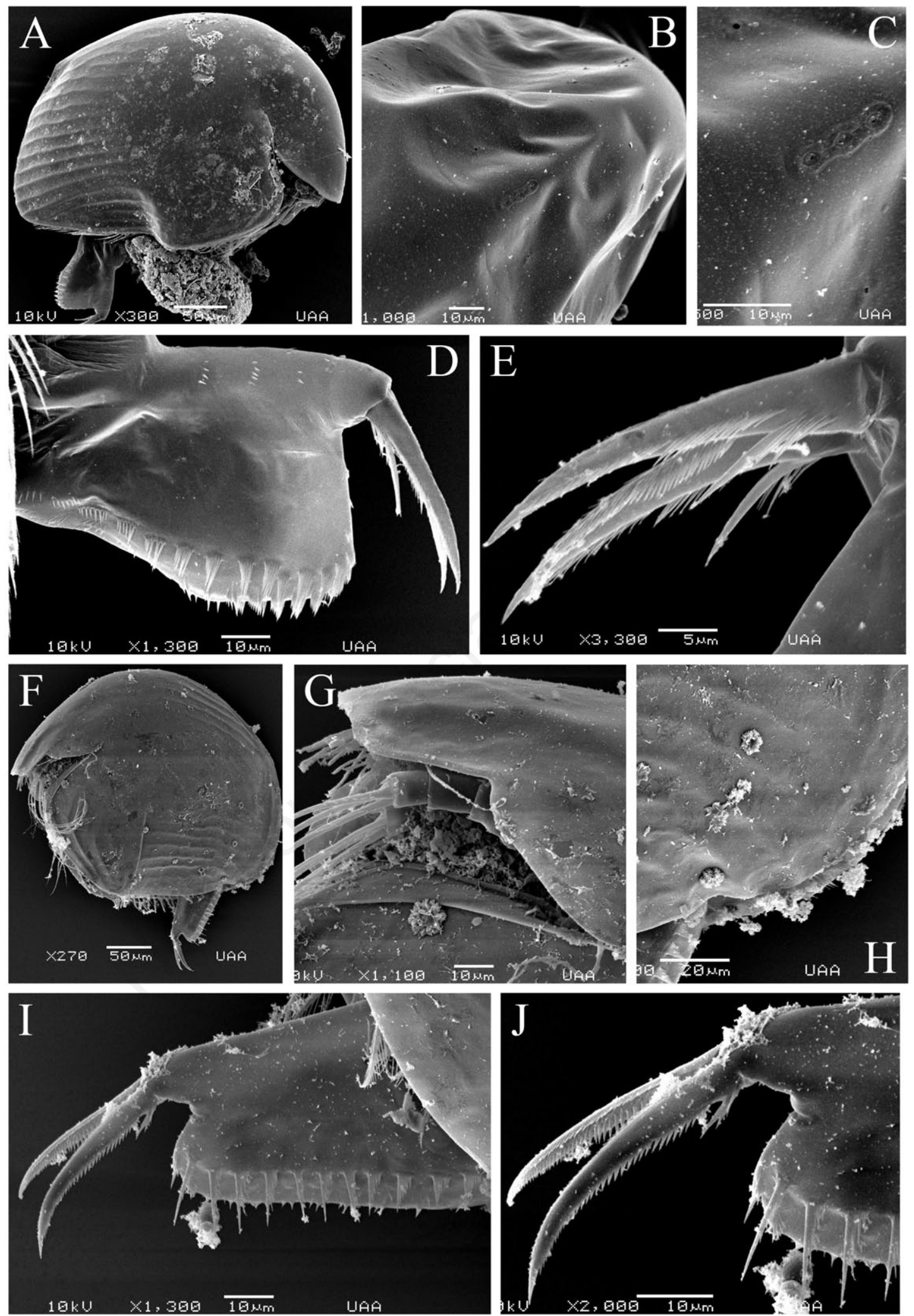

Fig. 12. Scanning electron microscopy of Aloninae from Vientiane municipality, Laos. A-E) Nicsmirnovius eximius, parthenogenetic female from LV08 - Ban Nonsa-art rice field: A) General view; B,C) head pores, dorsal view; D,E) postabdomen; F-J) Notoalona globulosa, parthenogenetic female from LV11 - Hui Sawn swamp 2: F) general view; G) head, lateral view; H) postero-ventral valve portion; I-J) postabdomen. 
ples (Van Damme et al., 2003), as such habitats are rarely sampled.

\section{Notoalona Rajapaksa \& Fernando, 1987}

Notoalona globulosa globulosa (Daday, 1898) (Fig. 12F-J). Described from Sri Lanka (Daday, 1898) as Alona, then moved to Indialona by Smirnov (1971) and later to Notoalona (Rajapaksa and Fernando, 1987c). The latter authors concluded that $N$. globulosa occurs also in the tropical part of the New World, and subsequently similar populations were also found in Southern Mexico (Elías-Gutiérrrez et al., 2006, 2008). In the Old World, records refer to $N$. globulosa, $N$. cf. freyi and one new species (Van Damme et al., 2013), yet we found only $N$. globulosa.

\section{Oxyurella Dybowski \& Grochowski, 1894}

Oxyurella singalensis (Daday, 1898). Originally described from Sri Lanka (Daday, 1898) and later recorded from tropical countries in the Old World (Smirnov, 1971). It is an easily recognisable species with relatively wide distribution. Males have been described by Sinev and Sanoamuang (2011) from Thailand.

\section{Subfamily Chydorinae Dybowski \& Grochowski, 1894 emend. Frey 1967}

\section{Alonella Sars, 1862}

Alonella cf. excisa (Fischer, 1854) (Figs. 13 and 14). Described from European Russia (Fischer, 1854) and now regarded as a widely distributed species (Smirnov, 1971),
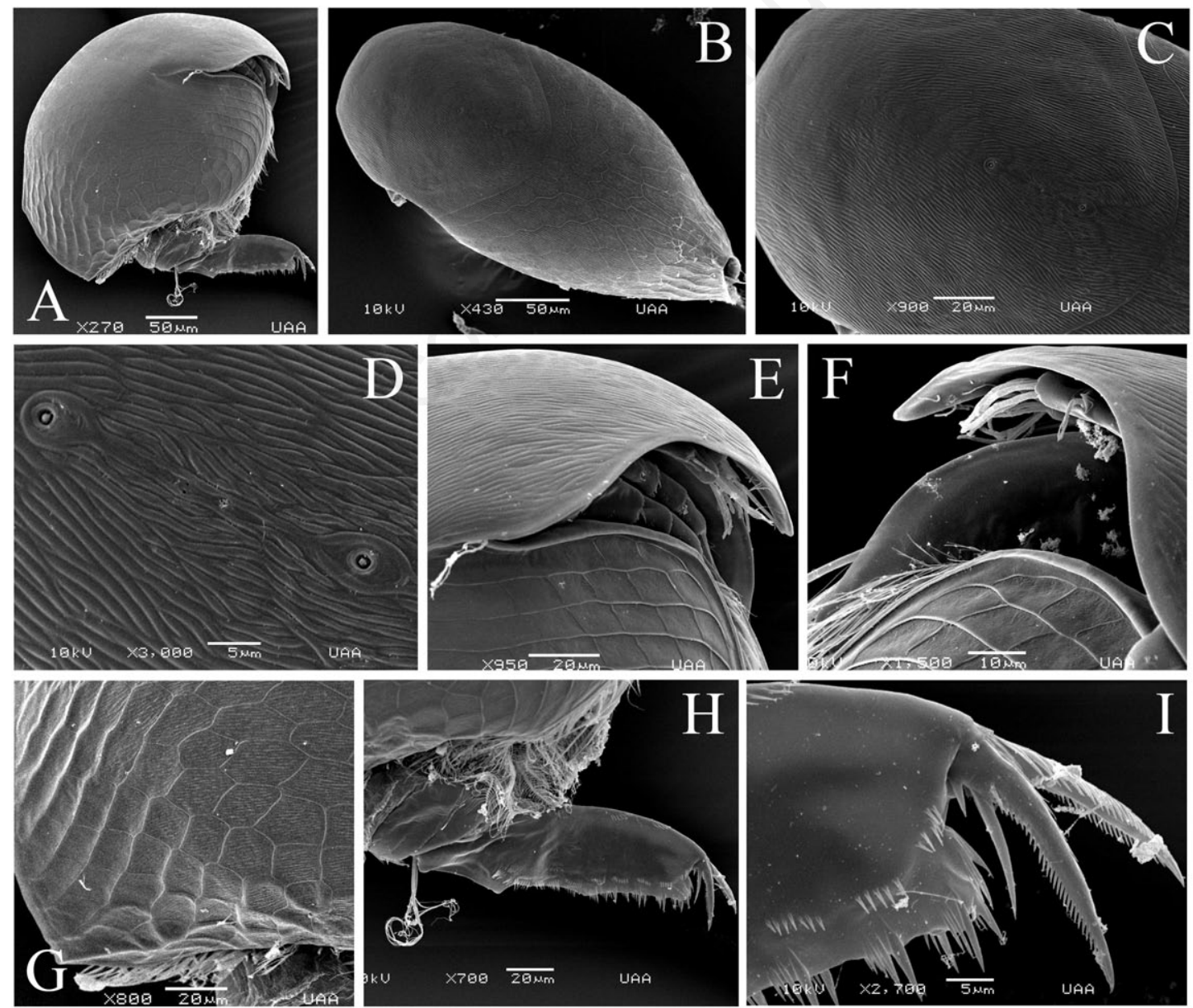

Fig. 13. Scanning electron microscopy of Alonella cf. excisa, morphotype 1, parthenogenetic female from VP3.1 - Ban Sansa-art fish pond, Vientiane municipality, Laos. A) General view; B) dorsal view; C,D) head pores; E,F) head, lateral view; G) postero-ventral valve portion; H,I) postabdomen and postabdominal claws. 
most likely species complex (Smirnov, 1996). Again, the Laotian populations form two morphotypes that differ in: i) expression of the small-sized striation between the reticulation meshes [strong (Fig. 13C, 13D, and 13G) vs weak (Fig. 14D, 14F-G)]; ii) length of rostrum [short (Fig. 13E and 13F) vs long (Fig. 14B)]; iii) shape of the distal portion of the postabdomen [dorso-distal angle projected (Fig. 13H and 13I) vs not projected at all (Fig. 14H and 14I)]; iv) relative size of the basal spine on the postabdominal claw [longer than half of the claw length (Fig. 13I) vs shorter (Fig. 14I)]. This could indicate the presence of two different species even in SE Asia.

\section{Chydorus Leach, 1816}

Chydorus cf. eurynotus Sars, 1901 (Fig. 15A-D). Des- cribed from Brazil (Sars, 1901), and widely distributed in the Neotropics, but found worldwide in tropical and subtropical regions (Smirnov, 1996). In comparison to the Neotropical populations, the SE Asian forms are still poorly understood and need a revision. The male morphology is discussed and some drawings of the Brazilian type material of true $C$. eurynotus are provided by Van Damme and Dumont (2010).

Chydorus obscurirostris tasekberae Frey, 1987 (Fig. $16 \mathrm{G}$ and $16 \mathrm{H})$. A honeycombed Chydorus, described from Malaysia (Frey, 1987) (the other subspecies - C. o. obscurirostris Frey, 1987 - is from Australia) and mentioned as subspecies or as C. obscurirostris (Maiphae et al., 2008 ) in the region. Other honeycombed species are also present in SE Asia and might be expected in Laos (e.g. C. opacus Frey, 1987).
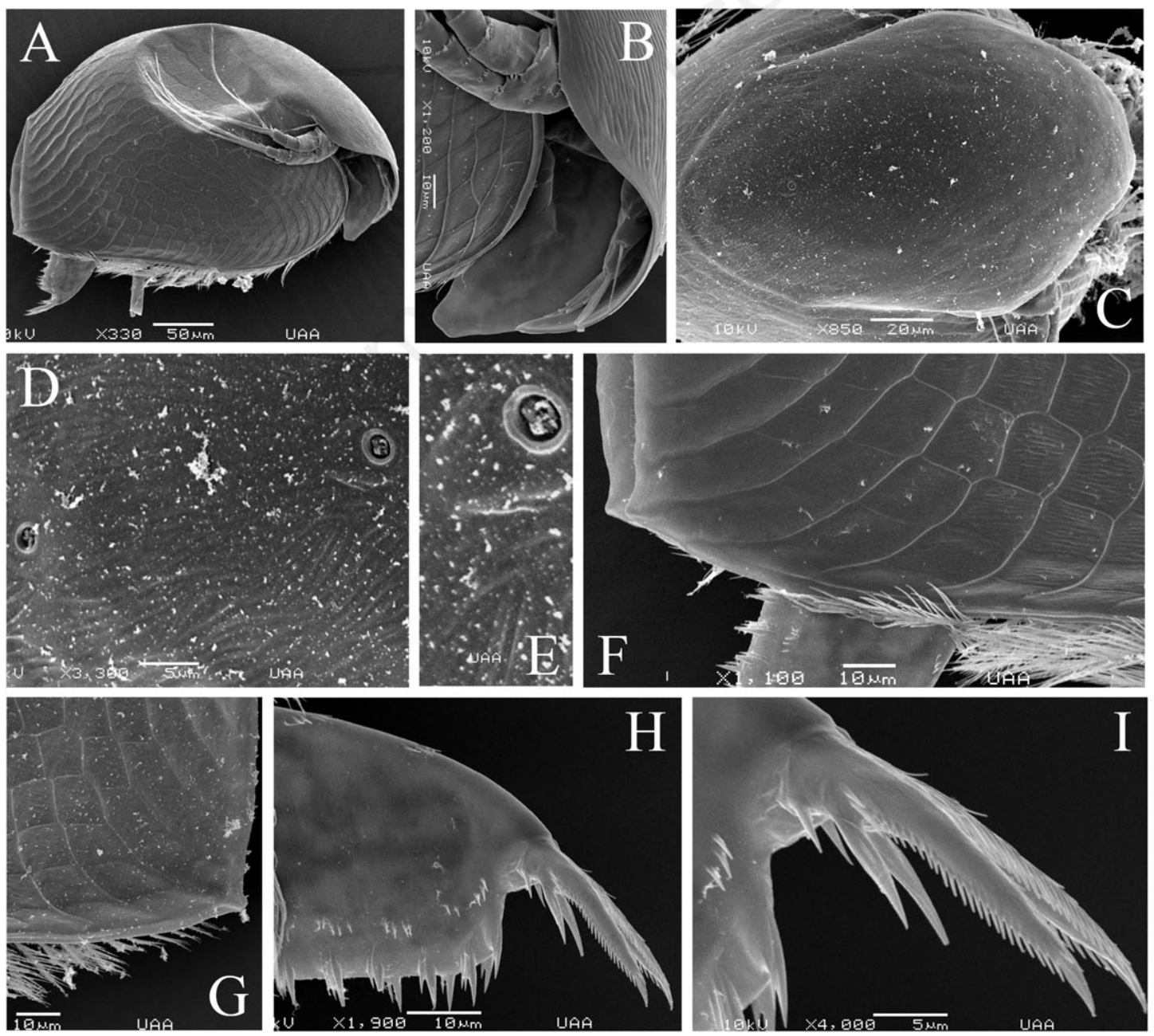

Fig. 14. Scanning electron microscopy of Alonella cf. excisa, morphotype 2, parthenogenetic female from VP1.1 - Ban Phang Hang fish pond, Vientiane municipality, Laos. A) General view; B) head; C) dorsal view; D,E) head pores; F,G) postero-ventral valve portion; $\mathrm{H}, \mathrm{I})$ postabdomen. 
Chydorus parvus Daday, 1898. Described from Sri Lanka by Daday (1898) and easily recognisable by the projection(s) inside the frontal valve margin. It is common in SE Asia and the Laotian records of this species are confirmed here, but other tropical populations outside the Oriental region should be revised.

Chydorus cf. pubescens Sars, 1901 (Fig. 17). Similarly to $C$. eurynotus, $C$. pubescens is a species described from Brazil (Sars, 1901), with wide distribution in the tropics (Smirnov, 1996), which needs to be revised. This species is very easily recognisable by its hairy carapace. There are numerous records from SE Asia (Idris and Fernando, 1981; Korovchinsky, 2013a; Maiphae et al., 2008), but those might eventually refer to a sibling species.

Chydorus reticulatus Daday, 1898 (Fig. 16A-F). Oriental species described from Sri Lanka (Daday, 1898). It was expected to occur in Laos as well, as it is known from the neighbouring countries and common in SE Asia (e.g. Sanoamuang, 1998; Smirnov, 1996).

Chydorus ventricosus Daday, 1898 (Fig. 15E and $15 F)$. Very common, large Oriental species that is ex- pected throughout the region. Records from the rest of the tropics should be revised, as this is likely a group of species.

\section{Dadaya Sars, 1901}

Dadaya macrops (Daday, 1898) (Fig. 18). Described from Sri Lanka (Daday, 1898) as Alona, then placed in the genus Dadaya (Sars, 1901). It is regarded as circumtropical (Smirnov, 1971, 1996; Rajapaksa and Fernando, 1982).

\section{Disparalona Fryer, 1968}

Disparalona hamata (Birge, 1879) (Fig. 19). It was described from North America (Birge, 1879), but $D$. hamata is common in East Asia, from the tropics to Korean peninsula and the Amur basin (Kotov et al., 2011, 2012) and present even in Europe (Hudeč, 2010). Sinev and Sanoamuang (2011) found that males of the Thai populations differ from the North America ones, which may indicate that the Thai form belongs to a separate species.

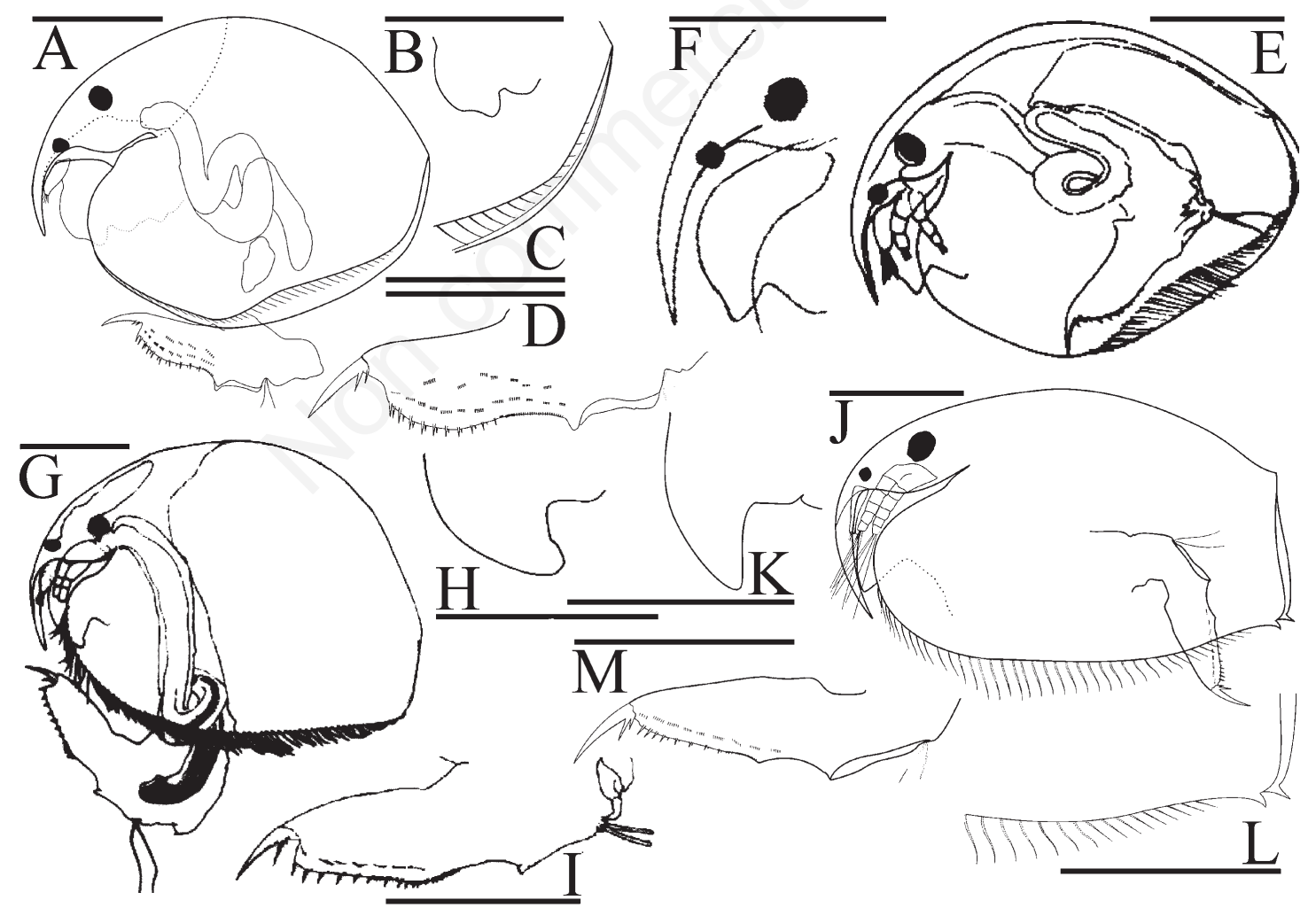

Fig. 15. Chydorinae from Vientiane province, Laos. A-D) Chydorus eurynotus from Nam Ngum dam, adult in general view, labral keel, postero-ventral portion of valve and postabdomen; E,F) Chydorus ventricosus from Nong Suem swamp 2, lateral view and head; G-I) Picripleuroxus cf. laevis from from Phonexay bridge (Roadside channel), adult in lateral view, labral keel, postero-ventral valve portion and postabdomen; J-M) Picripleuroxus cf. denticulatus from Ban Sansa-art fish pond, lateral view, labral keel and postabdomen. Scale bars: $0.1 \mathrm{~mm}$. 


\section{Dunhevedia King, 1853}

Dunhevedia crassa King, 1853. Described from Australia (King, 1853) and regarded as a cosmopolitan taxon (Smirnov, 1996). It needs to be revised worldwide.

Dunhevedia serrata Daday, 1898. Described from Sri Lanka (Daday, 1898) and distributed in the tropics of the Old World (Rajapaksa and Fernando, 1987d; Smirnov, 1996).

\section{Ephemeroporus Frey, 1982}

Ephemeroporus cf. barroisi (Richard, 1894) (Fig. 20). Described from Syria (Richard, 1894) as Pleuroxus, then moved to a special genus Ephemeroporus (Frey, 1982b) and found to be tropicopolitan (Smirnov, 1996; Kotov et al., 2011, 2012). It is widely distributed in other SE Asian countries (Maiphae et al., 2005, 2008; Tanaka and Ohtaka, 2010; Korovchinsky, 2013a). Maiphae et al. (2005, 2008) identified three other species of the genus Ephemeroporus from Thailand, but all our populations were similar to Ephemeroporus barroisi. This species is not described in detail and needs to be revised in the future.

\section{Picripleuroxus Frey, 1993}

Picripleuroxus cf. denticulatus (Birge, 1879) (Fig. 15G-I). Described from the USA (Birge, 1879) and found to be common in the tropics-subtropics, penetrating Europe (Hudeč and Illyová, 1998) in the west and the Amur basin (Kotov et al., 2011) in East Eurasia. It is relatively common in SE Asian countries (Sinev and Sanoamuang, 2011; Korovchinsky, 2013a). This group definitively needs to be revised worldwide. The Asian populations belong to a separate taxon awaiting a formal description; our record might refer to $P$. quasidenticulatus Smirnov, 1966, having a distinctively short and robust postabdominal claw (Sinev, personal communication), yet this species
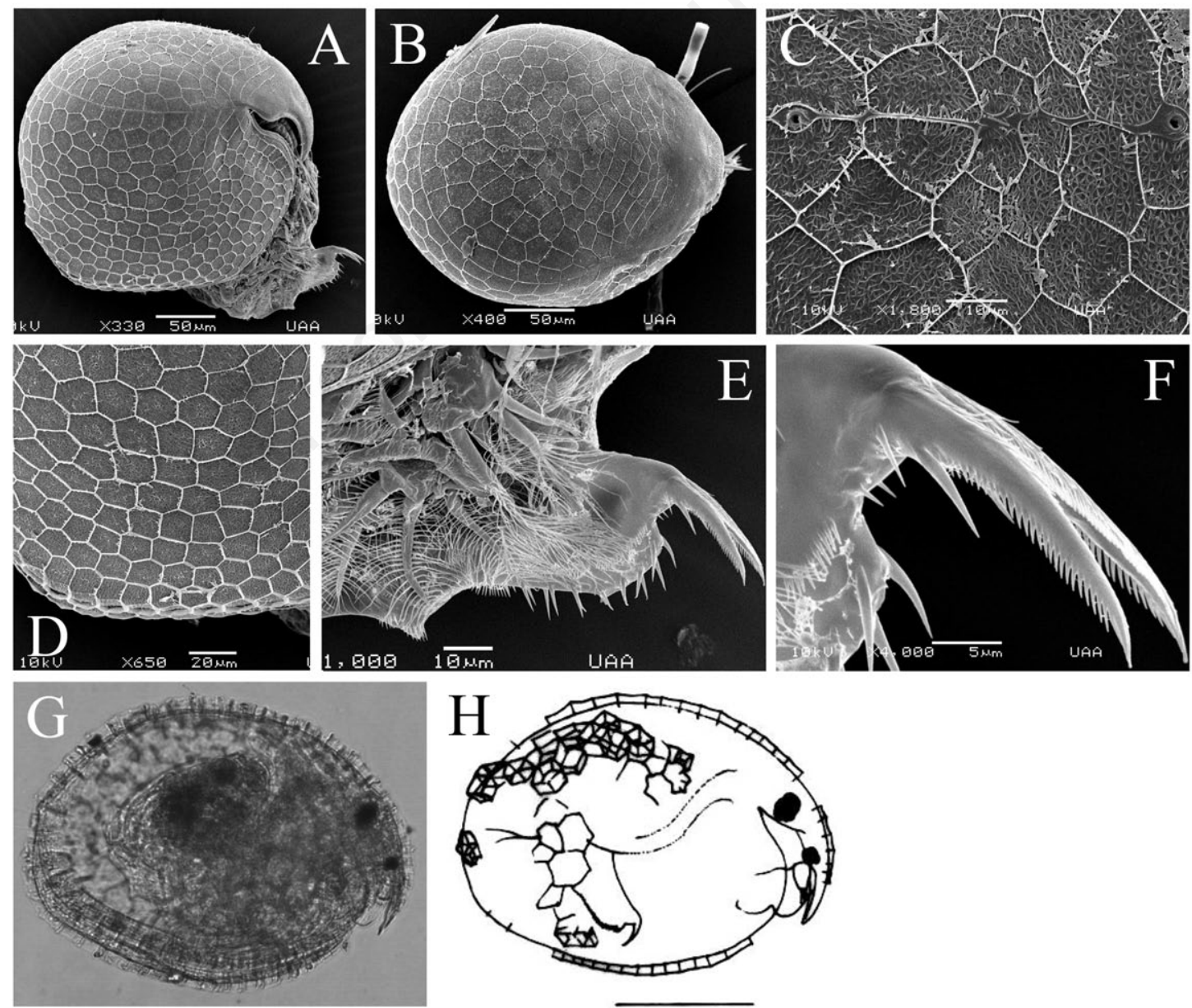

Fig. 16. Chydorus from Vientiane municipality, Laos. A-F) Scanning electron microscopy of C. reticulatus, parthenogenetilc female from VP1.1 - Ban Phang Hang fish pond: A) general view; B) dorsal view; C) head pores; D) postero-ventral valve portion; E,F) postabdomen. G-H) C. obscurirostris tasekberae from LV08 - Ban Nonsa-art rice field, lateral view. 
also needs redescription. The latter species has also been found in Vietnam (Sinev and Korovchinsky, 2013).

Picripleuroxus laevis Sars, 1862 (Fig. 15J-L). Described from Northern Europe (Norway) (Sars, 1862). In fact, it is a widely distributed species complex, the revision of which was started by Frey (1988) but never tackled since then. Picripleuroxus laevis-like populations have been also found in other SE Asian countries and need to be revised. There are serious objections to the separation of the genus Picripleuroxus from Pleuroxus Baird, 1843 (Chiambeng and Dumont, 2004; Smirnov et al., 2006), which means that future revisions need to include a larger set of the species.

\section{Species richness during rainy and wet season}

Tabs. 1-3 demonstrate the results of our comparison of the dry- and rainy-season fauna of the Cladocera in Vientiane province and municipality. Our sampling represents a realistic biodiversity for the region, as the estimations from the models are only somewhat higher than the empirical numbers (Tab. 2). The number of species during the dry season (both empirical and estimated by models) is only about $20 \%$ smaller than the species number during the rainy season. During both rainy and dry seasons a similar set of dominant species occurs (Tab. 3). Almost all species, revealed for this territory, are present during the rainy season; still, both maximum and average number of species per sample is two times higher in the rainy season and relative abundances shift between the seasons.

\section{DISCUSSION}

Most publications on tropical cladocerans concern zooplankton only, not the benthic or the littoral species. It means that only a very small portion of the biodiversity is revealed in such papers. The total number of littoral forms is significantly higher than the number of planktonic taxa in SE Asia (Idris, 1983; Tanaka and Ohtaka, 2010) and in fact, everywhere. Our study led to the finding of 70 cladoceran taxa in only a small portion of Laos, previously almost unknown to cladoceran taxonomists. We can conclude that our sampling was relatively full and adequate: our model estimations suggest the presence of about 77 species in this territory. We
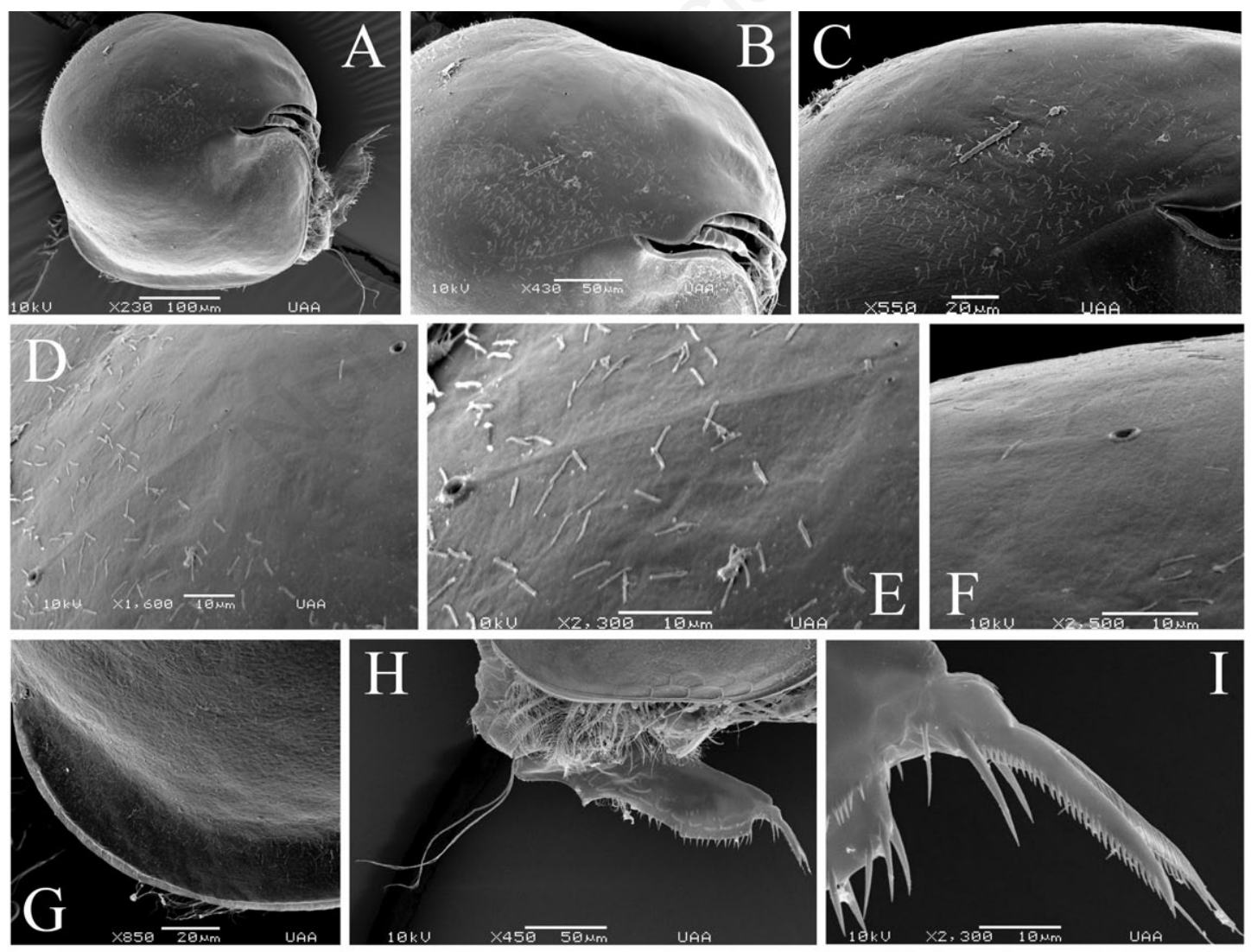

Fig. 17. Scanning electron microscopy of Chydorus cf. pubescens, parthenogenetic female from VP3.1 - Ban Sansa-art fish pond, Vientiane municipality, Laos. A) General view; B) head; C-D) region of head pores; E,F) head pores; G) postero-ventral valve portion; H,I) postabdomen and postabdominal claws. 
found that differences between the rainy and dry seasons in the dominant species complexes are small, but many rare species are absent during the dry season. Therefore, intense collection during different seasons - not just in one season - in the tropics is necessary for an adequate description of the cladoceran faunas.

This is the first detailed faunistic report published on the Laotian Cladocera, so the tally is far from complete. The species number shown here is not representative for the species richness of the country and should not be used as a standard. Several taxa that are present, or even common in the Oriental region, are still lacking. We can suggest a list of species which will be most probably found in Laos in the future, because they occur in other SE Asian countries (Maiphae et al., 2005, 2008; Tanaka and Ohtaka, 2010; Korovchinsky, 2013a, 2013b): Diaphanosoma volzi Stin- gelin, 1905; D. elongatum Korovchinsky \& Sanoamuang, 2008; Macrothrix pholpunthini Kotov, Maiphae \& Sanoamuang, 2006; M. malaysiensis Idris \& Fernando, 1981; Guernella cf. raphaelis Richard, 1892; Bosmina cf. longirostris (O. F. Müller, 1785); B. fatalis Burckhardt, 1924; Graptoleberis cf. testudinaria (Fischer, 1848); Alonella cf. nana (Baird, 1843); A. clathratula (Sars, 1896); Disparalona caudata Smirnov, 1996; Chydorus sinensis Frey, 1987; C. opacus Frey, 1987; Pseudochydorus cf. globosus (Baird, 1843), etc. The absence of these taxa does not reflect a natural phenomenon but it is just a simple result from sampling bias.

Ponthalith (2006) reported on 40 cladoceran taxa in Champasak province of Laos, with few taxa different from those of our list. Among ctenopods, he recorded D. voltzi Stingelin, 1905, D. modigliani Richard, 1894, and D. sene-
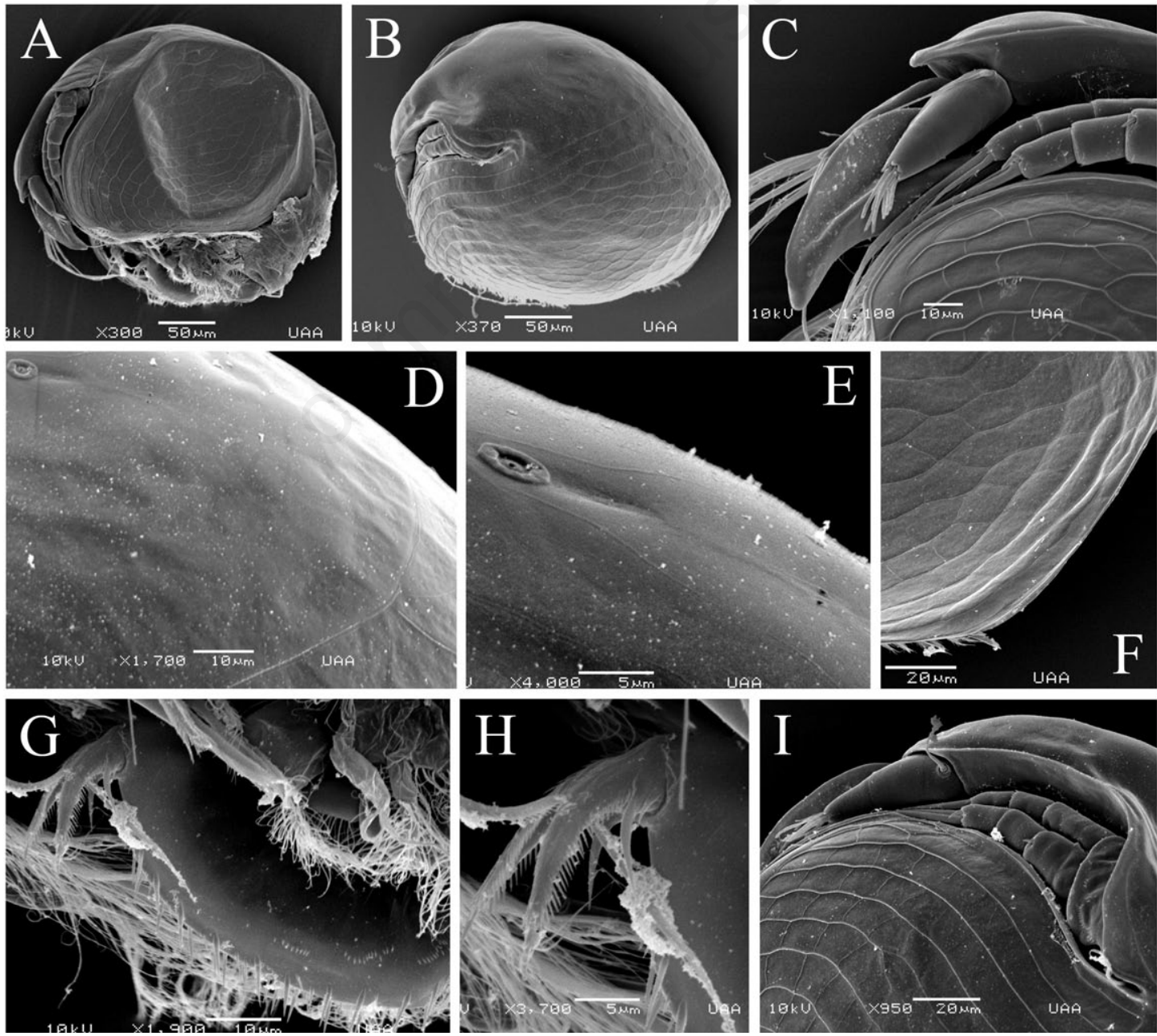

Fig. 18. Scanning electron microscopy of Dadaya macrops, parthenogenetic female from LV03 - Nong Suem lotus pond, Vientiane municipality, Laos. A-B) General view; C) labral keel and antenna I; D,E) head pores; F) postero-ventral valve portion; G,H) postabdomen and postabdominal claws; I) antenna I and II. 
gal Gauthier, 1951. But Korovchinsky (2013b), re-studying these samples, confirmed only the latter determination (as D. senegal isanensis Korovchinsky \& Sanoamuang, 2008). While the presence of $D$. voltzi in Laos is possible (it is present in neighboring Thailand), the finding of $D$. modigliani seems to be very dubious (Korovchinsky, 2013b). Chydorus cf. brevilabris Frey, 1980 in the list of Ponthalith (2006) seems to be a misidentification, but then again Chydorus is a very difficult genus for which no good revision exists. Ephemeroporus cf. epiaphantoii Alonso, 1987 is also recorded from Thailand (Maiphae et al., 2008). The genus Ephemeroporus contains several species in SE Asia and needs to be revised. Therefore, at least some species absent in our list were previously found in Laos, but these results remain unpublished.

Earlier Tanaka and Ohtaka (2010) found 60 taxa in 21 samples collected in the vicinities of Lake Tonle Sap, while Idris (1983) recorded only 62 species in the whole of Malaysia. In Thailand, Maiphae et al. $(2005,2008)$ reached a realistic stable species diversity of around $c a .100$ species. Even so, new taxa and records are being found (Van Damme et al., 2013) and there is also a lot to be revised among the known species groups with representatives throughout the tropics (Korovchinsky, 2013a). Among these, species that have been described in the Neotropics, Palaearctic or in the Afrotropics and that form widespread species groups, should be evaluated in detail (e.g. C. pubescens, C. eurynotus, A. affinis, A. costata, etc.) (Korovchinsky, 2013a). The same goes for other countries in the Oriental region where recent taxonomical efforts have been made (Thailand - Maiphae et al., 2008; India - Chatterjee et al., 2013). Some records of the species described from other continents and from other SE Asian countries, such as Onchobunops cf. tuberculatus Fryer \& Paggi, 1981, Leydigia australis Sars, 1885 or Chydorus dentifer Daday, 1905 (Tanaka and Ohtaka, 2010), are likely separate species and need to be formally described.

An increase of the country's biodiversity can be expected after accurate revisions of some of the most difficult groups: Ceriodaphnia, Alona and Chydorus. In the former two genera, all populations which are now assigned to taxa described from Europe, probably compose of groups of cryptic species with unknown distribution: tropical, or tropicopolitan, or endemics of SE Asia.
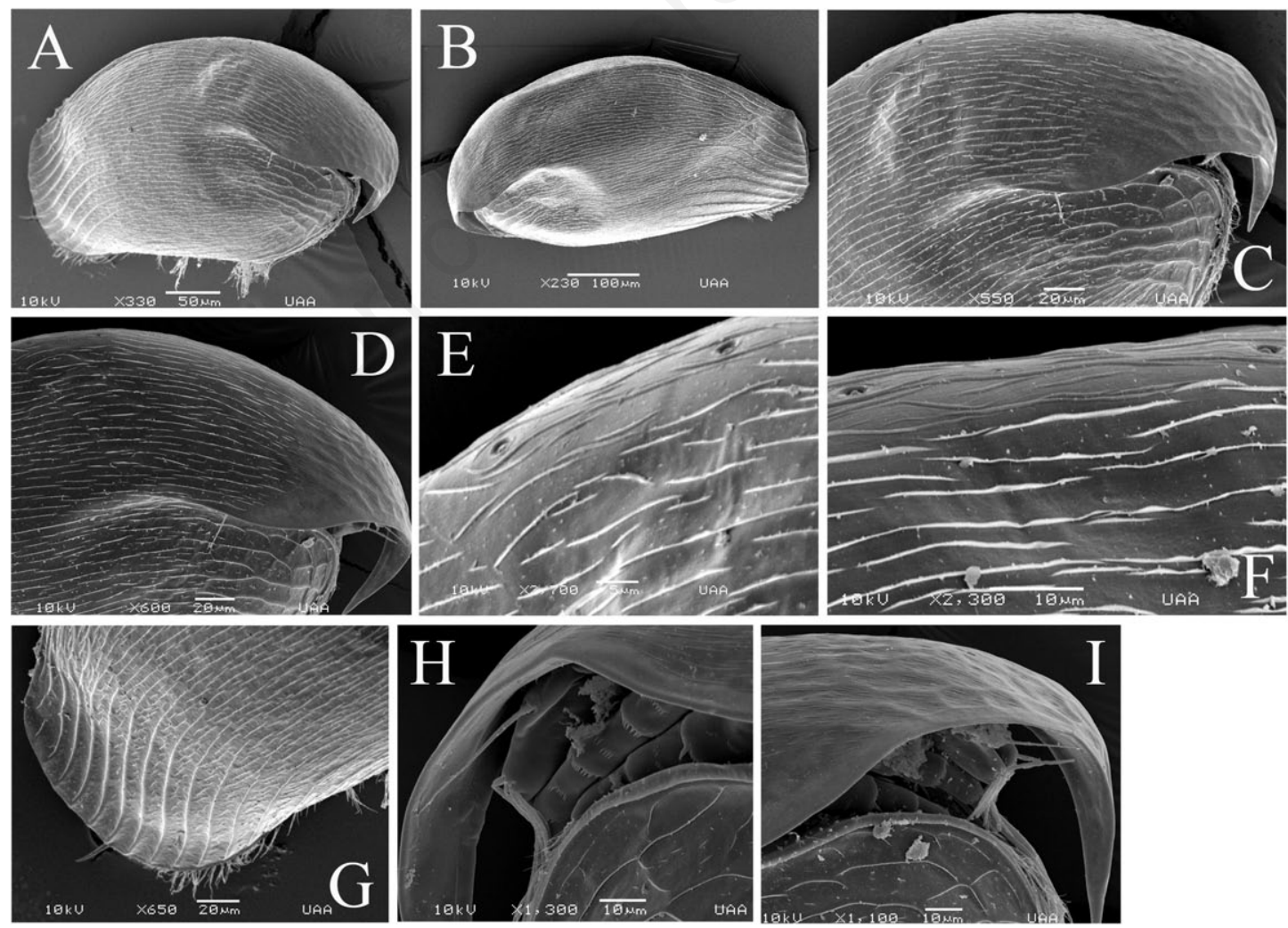

Fig. 19. Scanning electron microscopy of Disparalona hamata, parthenogenetic female from LV08 - Ban Nonsa-art rice field, Vientiane municipality, Laos. A,B) General view; C,D) head, region of head pores; E,F) head pores; G) postero-ventral valve portion; H,I) head with antenna I and II. 
Hence, it is too early to draw conclusions on the comparative richness of the Laotian Cladocera and it is clear that further surveys will allow more realistic numbers. In any case, with this work, we hope that an important step has been made towards the knowledge of the Laotian cladocerans.

\section{CONCLUSIONS}

The study of the cladoceran fauna of Laos is now in its initial phase. In the Results section, we used the ex- pression needs to be revised too often. This comes as a result of the recent state of the cladoceran taxonomy in SE Asia and in fact, in the tropics worldwide. Recent morphological studies using new standards and techniques can significantly increase the biodiversity estimates and the number of cladoceran endemics in different regions (and can be tested by molecular methods). We believe that Laos in particular and SE Asia in general will not be an exception to this rule. Now that the taxonomical foundations have been built, the future step is to increase sampling efforts in Laos in terms of areas and types of habitats
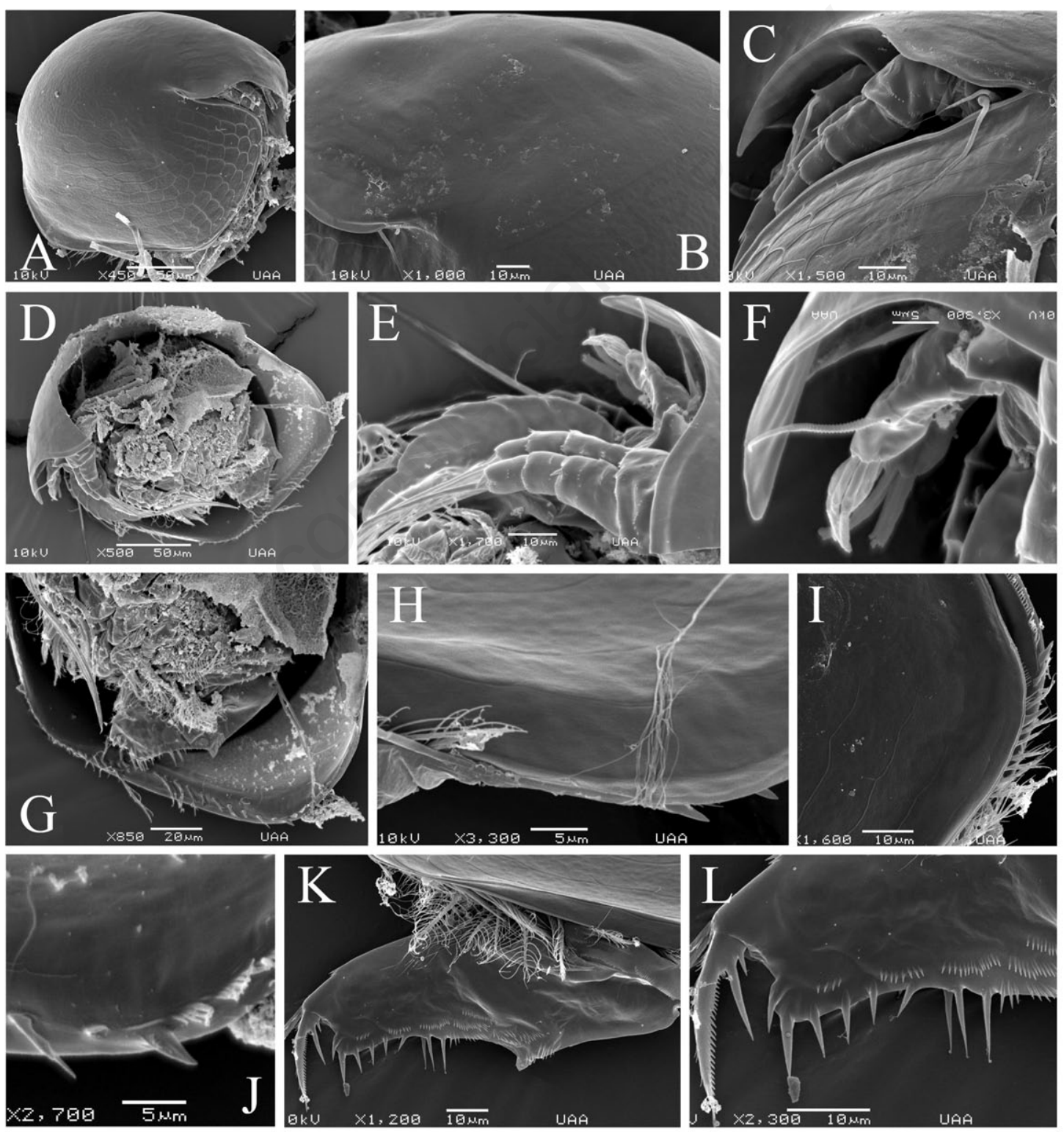

Fig. 20. Scanning electron microscopy of Ephemeroporus cf. barroisi, parthenogenetic female from VP3.1 - Ban Sansa-art fish pond, Vientiane municipality, Laos. A) General view; B) region of head pores; C) head, lateral view; D) general view, valve removed; E) labral keel, antenna I and antenna II; F) antenna I; G-J) postero-ventral valve portion; K,L) postabdomen. 
Tab. 1. Number of localities where the species were found at dry and rainy seasons.

\begin{tabular}{|c|c|c|c|c|c|}
\hline $\mathrm{N}$. & Family & Taxon & $\begin{array}{l}\text { Records in all } \\
97 \text { samples (n) }\end{array}$ & $\begin{array}{c}\text { Records in } \\
39 \text { samples } \\
\text { from dry season } \\
2010(\mathrm{n})\end{array}$ & $\begin{array}{c}\text { Records in } \\
36 \text { samples } \\
\text { from rainy } \\
\text { season } 2011(\mathrm{n})\end{array}$ \\
\hline 1 & Chydoridae & Acroperus harpae (Baird, 1834)* & 1 & 0 & 1 \\
\hline 2 & Chydoridae & Alona cf. affinis Leydig, 1860 & 14 & 5 & 9 \\
\hline 3 & Chydoridae & Alona cambouei Guerne \& Richard, 1893 & 12 & 3 & 9 \\
\hline 4 & Chydoridae & Alona cf. costata Sars, 1862 & 13 & 3 & 10 \\
\hline 5 & Chydoridae & Alona cf. guttata Sars, 1862 & 3 & 1 & 2 \\
\hline 6 & Chydoridae & Alona kotovi Sinev, 2012* & 1 & 0 & 1 \\
\hline 7 & Chydoridae & Alona sarasinorum Stingelin, 1900 & 6 & 1 & 5 \\
\hline 8 & Chydoridae & Alona siamensis Sinev \& Sanoamuang, $2007^{*}$ & 1 & 0 & 1 \\
\hline 9 & Chydoridae & Alonella cf. excisa (Fischer, 1854) & 27 & 8 & 13 \\
\hline 10 & Chydoridae & Anthalona harti Van Damme, Sinev \& Dumont, 2011 & 52 & 14 & 29 \\
\hline 11 & Chydoridae & Anthalona sanoamuangae Sinev \& Kotov, 2012* & 2 & 0 & 2 \\
\hline 12 & Bosminidae & Bosmina meridionalis Sars, 1904 & 11 & 4 & 3 \\
\hline 13 & Bosminidae & Bosminopsis deitersi Richard, 1895 & 42 & 19 & 18 \\
\hline 14 & Chydoridae & Camptocercus vietnamensis Thang, 1980 & 5 & 2 & 3 \\
\hline 15 & Chydoridae & Celsinotum macronyx (Daday, 1898)* & 3 & 0 & 3 \\
\hline 16 & Daphniidae & Ceriodaphnia cornuta Sars, 1888 & 43 & 17 & 19 \\
\hline 17 & Daphniidae & Ceriodaphnia cf. laticaudata P.E. Müller, 1867 & 1 & 1 & 0 \\
\hline 18 & Daphniidae & Ceriodaphnia reticulata (Jurine, 1820) & 2 & 0 & 2 \\
\hline 19 & Chydoridae & Chydorus eurynotus Sars, 1901 & 47 & 10 & 25 \\
\hline 20 & Chydoridae & Chydorus obscurirostris tasekberae Frey, $1987^{*}$ & 2 & 0 & 2 \\
\hline 21 & Chydoridae & Chydorus parvus Daday, 1898 & 11 & 3 & 8 \\
\hline 22 & Chydoridae & Chydorus cf. pubescens Sars, 1901 & 3 & 2 & 0 \\
\hline 23 & Chydoridae & Chydorus reticulatus Daday, 1898 & 17 & 5 & 12 \\
\hline 24 & Chydoridae & Chydorus ventricosus Daday, 1898 & 15 & 3 & 10 \\
\hline 25 & Chydoridae & Coronatella cf. monacantha (Sars, 1901) & 2 & 1 & 1 \\
\hline 26 & Chydoridae & Coronatella cf. rectangula Sars, 1862 & 20 & 4 & 13 \\
\hline 27 & Chydoridae & Coronatella sp.* & 1 & 0 & 0 \\
\hline 28 & Chydoridae & Dadaya macrops (Daday, 1898)* & 7 & 0 & 4 \\
\hline 29 & Sididae & Diaphanosoma dubium Manuilova, 1946 & 8 & 4 & 4 \\
\hline 30 & Sididae & Diaphanosoma excisum Sars, 1885 & 72 & 32 & 31 \\
\hline 31 & Sididae & Diaphanosoma sarsi Richard, 1895 & 19 & 6 & 13 \\
\hline 32 & Sididae & Diaphanosoma sp. & 4 & 2 & 2 \\
\hline 33 & Daphniidae & Daphnia lumholzi Sars, 1885 & 2 & 0 & 0 \\
\hline 34 & Chydoridae & Disparalona hamata (Birge, 1879) & 5 & 3 & 0 \\
\hline 35 & Chydoridae & Dunhevedia crassa King, 1853* & 2 & 0 & 1 \\
\hline 36 & Chydoridae & Dunhevedia serrata Daday, $1898^{*}$ & 4 & 0 & 4 \\
\hline 37 & Chydoridae & Ephemeroporus cf. barroisi (Richard, 1894) & 56 & 15 & 32 \\
\hline 38 & Chydoridae & Euryalona orientalis (Daday, 1898) & 6 & 1 & 4 \\
\hline 39 & Macrothricidae & Grimaldina brazzai Richard, 1892 & 4 & 2 & 2 \\
\hline 40 & Ilyocryptidae & Ilyocryptus spinifer Herrick, 1882 & 39 & 12 & 23 \\
\hline 41 & Ilyocryptidae & Ilyocryptus thailandensis Kotov \& Sanoamuang, 2004* & 2 & 0 & 2 \\
\hline 42 & Chydoridae & Karualona cf. iberica (Alonso \& Pretus, 1989)* & 1 & 0 & 1 \\
\hline 43 & Chydoridae & Karualona cf. karua (King, 1853) & 23 & 5 & 15 \\
\hline 44 & Chydoridae & Karualona cf. kwangsiensis Jiang, 1963 & 2 & 1 & 1 \\
\hline 45 & Chydoridae & Karualona sp. 2 (sp. nov.) $)^{*}$ & 1 & 0 & 1 \\
\hline 46 & Chydoridae & Kurzia brevilabris Rajapaksa \& Fernando, 1986 & 11 & 5 & 6 \\
\hline 47 & Chydoridae & Kurzia longirostris (Daday, 1898) & 10 & 3 & 7 \\
\hline 48 & Sididae & Latonopsis australis Sars, 1888 & 8 & 1 & 6 \\
\hline 49 & Chydoridae & Leberis diaphanus (King, 1853)* & 8 & 0 & 4 \\
\hline 50 & Chydoridae & Leberis sp. & 12 & 1 & 11 \\
\hline 51 & Chydoridae & Leydigia ciliata Gauthier, 1939 & 4 & 1 & 3 \\
\hline 52 & Chydoridae & Leydigiopsis sp. & 3 & 1 & 2 \\
\hline 53 & Macrothricidae & Macrothrix odiosa Gurney, $1916^{*}$ & 5 & 0 & 4 \\
\hline 54 & Macrothricidae & Macrothrix vietnamensis Silva-Briano, Dieu \& Dumont, 1999 & 4 & 2 & 2 \\
\hline 55 & Macrothricidae & Macrothrix spinosa King, 1852 & 50 & 16 & 24 \\
\hline 56 & Macrothricidae & Macrothrix triserialis Brady, 1886 & 43 & 13 & 25 \\
\hline 57 & Chydoridae & Matralona freyi Idris \& Fernando, $1980^{*}$ & 1 & 0 & 1 \\
\hline 58 & Moinidae & Moina micrura Kurz, 1874 & 34 & 15 & 15 \\
\hline 59 & Moinidae & Moina brachiata (Jurine, 1820) & 1 & 0 & 1 \\
\hline 60 & Moinidae & Moinodaphnia maclaeyi (King, 1853) & 22 & 3 & 16 \\
\hline 61 & Chydoridae & Nicsmirnovius eximius (Kiser, 1948) & 11 & 3 & 7 \\
\hline
\end{tabular}


Tab. 1. Continued from previous page.

\begin{tabular}{|c|c|c|c|c|c|}
\hline $\mathrm{N}$. & Family & Taxon & $\begin{array}{l}\text { Records in all } \\
97 \text { samples (n) }\end{array}$ & $\begin{array}{l}\text { Records in } \\
39 \text { samples } \\
\text { from dry season } \\
2010(\mathrm{n})\end{array}$ & $\begin{array}{l}\text { Records in } \\
36 \text { samples } \\
\text { from rainy } \\
\text { season } 2011(\mathrm{n})\end{array}$ \\
\hline 62 & Chydoridae & Notoalona globulosa globulosa (Daday, 1898) & 11 & 4 & 6 \\
\hline 63 & Chydoridae & Oxyurella singalensis (Daday, 1898) & 8 & 3 & 5 \\
\hline 64 & Chydoridae & Picripleuroxus cf. denticulatus (Birge, 1879)* & 1 & 0 & 0 \\
\hline 65 & Chydoridae & Picripleuroxus laevis Sars, 1862 & 6 & 3 & 3 \\
\hline 66 & Sididae & Pseudosida szalayi (Daday, 1898) & 11 & 1 & 9 \\
\hline 67 & Daphniidae & Scapholeberis kingi Sars, 1903 & 15 & 3 & 11 \\
\hline 68 & Daphniidae & Simocephalus congener (Koch, 1841) & 1 & 1 & 0 \\
\hline 69 & Daphniidae & Simocephalus heilonjangensis Shi \& Shi, 1994 & 3 & 2 & 0 \\
\hline 70 & Daphniidae & Simocephalus serrulatus (Koch, 1841) & 20 & 8 & 12 \\
\hline
\end{tabular}

"Species absent during dry season. Notice that species are rare during rainy season.

Tab. 2. Empiric and estimated number of species in Vientiane province, Laos using EstimateS.

\begin{tabular}{|c|c|c|c|c|c|}
\hline Variant & $\begin{array}{c}\text { Empiric number } \\
\text { of species }\end{array}$ & $\begin{array}{c}\text { Estimated number } \\
\text { of species }\end{array}$ & Best model & $\begin{array}{l}\text { Maximum number } \\
\text { of species in a sample }\end{array}$ & $\begin{array}{c}\text { Average number } \\
\text { per sample }\end{array}$ \\
\hline All data & 70 & 77 & Chao2 & 30 & 9.5 \\
\hline All data of 2010-2011 & 67 & 77 & Chao2 & 30 & 10.5 \\
\hline Only rainy season of 2011 & 62 & 72 & Jacknife1 & 30 & 14.1 \\
\hline Only dry season of 2010 & 50 & 59 & Chao2 & 15 & 7.1 \\
\hline
\end{tabular}

Tab. 3. Top ten most common species during all seasons, dry season and rainy season.

\begin{tabular}{|c|c|c|c|c|c|}
\hline \multicolumn{2}{|l|}{ All seasons } & \multicolumn{2}{|l|}{ Dry season } & \multicolumn{2}{|l|}{ Rainy season } \\
\hline Taxon & $\begin{array}{l}\text { Samples where } \\
\text { taxon was } \\
\text { found }(\%)\end{array}$ & Taxon & $\begin{array}{l}\text { Samples where } \\
\text { taxon was } \\
\text { found }(\%)\end{array}$ & Taxon & $\begin{array}{l}\text { Samples where } \\
\text { taxon was } \\
\text { found }(\%)\end{array}$ \\
\hline Diaphanosoma excisum & 74 & Diaphanosoma excisum & 82 & Ephemeroporus cf. barroisi & 89 \\
\hline Ephemeroporus cf. barroisi & 58 & Bosminopsis deitersi & 49 & Diaphanosoma excisum & 86 \\
\hline Anthalona harti & 54 & Ceriodaphnia cornuta & 44 & Anthalona harti & 81 \\
\hline Macrothrix spinosa & 52 & Macrothrix spinosa & 41 & Chydorus eurynotus & 69 \\
\hline Chydorus eurynotus & 48 & Ephemeroporus cf. barroisi & 38 & Macrothrix triserialis & 69 \\
\hline Macrothrix triserialis & 44 & Moina micrura & 38 & Macrothrix spinosa & 67 \\
\hline Ceriodaphnia cornuta & 44 & Anthalona harti & 36 & Ilyocryptus spinifer & 64 \\
\hline Bosminopsis deitersi & 43 & Macrothrix triserialis & 33 & Ceriodaphnia cornuta & 53 \\
\hline Ilyocryptus spinifer & 40 & Ilyocryptus spinifer & 31 & Bosminopsis deitersi & 50 \\
\hline Moina micrura & 35 & Chydorus eurynotus & 26 & Moinodaphnia maclaeyi & 86 \\
\hline
\end{tabular}

and to continue systematic efforts in order to assess the country's cladoceran biodiversity.

\section{ACKNOWLEDGMENTS}

AAK, KVD and SS participated in the Freshwater Invertebrates of SE Asia workshop in 2012 and thank Dr. Maria K. Hołyńska and Prof. La-orsri Sanoamuang for the financial support and organisation of this meeting. SS thanks the Thailand International Cooperation Agency (TICA) which supports a scholarship for her MA Thesis, and her supervisors (LS and KVD) for continuous help. EIB, MSB and AAO thanks the Applied Taxonomic Research Center, Khon Kaen University for the support of their stay in Thailand and chance to visit Laos.

The study is partly supported by the Russian Foundation for Basic Research (grants 12-04-00207-a and 12-0490857-мол рф нр), the Program of the Presidium of Russian Academy of Sciences Biodiversity: State and Dynamics (for AAK and EIB), and the National Research University Project of Thailand through the Holistic Watershed Management Cluster (for LS). 


\section{REFERENCES}

Adamowicz SJ, Purvis A, 2005. How many branchiopod crustacean species are there? Quantifying the components of underestimation. Global Ecol. Biogeogr. 14:455-468.

Alonso M, Pretus JL, 1989. Alona iberica, new species: first evidence of noncosmopolitanism within the A. karua complex (Cladocera, Chydoridae). J. Crustacean Biol. 9:459-476.

Benzie JAH, 2005. The genus Daphnia (including Daphniopsis) (Anomopoda: Daphniidae). Guides to the identification of the microinvertebrates of the continental waters of the world. Ghent and Backhuys Publ., Leiden: 376 pp.

Berner DB, 1985. Morphological differentiation among species in the Ceriodaphnia cornuta complex (Crustacea, Cladocera). Verh. Internat. Verein. Theor. Angew. Limnol. 22:3099-3103.

Birge EA, 1879. Notes on Cladocera. T. Wisc. Acad. Sci. 4:77-109.

Chatterjee T, Kotov AA, Van Damme K, Chandrasekhar SVA, Padhye S, 2013. An annotated checklist of the Cladocera (Crustacea: Branchiopoda) from India. Zootaxa 3667:1-89.

Chiambeng GY, Dumont HJ, 2004. The genus Pleuroxus Baird, 1843 (Crustacea: Anomopoda: Chydoridae) in Cameroon, Central-West Africa. Ann. Limnol.-Int. J. Lim. 40:211-229.

Colwell RK, 1997. EstimateS: statistical estimation of species richness and shared species from samples. Version 5. Available from: http://viceroy.eeb.uconn.edu/estimates

Daday E, 1898. [Mikroskopische Süsswasserthiere aus Ceylon]. [Article in German]. Természettudomanyi Füzetek 21:1-123.

de Guerne J, Richard J, 1893. [Canthocamptus grandidieri, Alona cambouei, nouveaux entomostracés d'eau douce de Madagaskar]. [Article in French]. Mém. Soc. Zool. France 6:234-244.

Dumont HJ, Silva-Briano M, Babu KKS, 2002. A re-evaluation of the Macrothrix rosea-triserialis group, with the description of two new species (Crustacea Anomopoda: Macrothricidae). Hydrobiologia 467:1-44.

Elías-Gutiérrez M, Kotov AA, Garfias-Espejo T, 2006. Cladocera (Crustacea: Ctenopoda, Anomopoda) from southern Mexico, Belize and northern Guatemala, with some biogeographical notes. Zootaxa 1119:1-27.

Elías-Gutiérrez M, Martínez Jerónimo F, Ivanova NV, Valdez Moreno M, Hebert PDN, 2008a. DNA barcodes for Cladocera and Copepoda from Mexico and Guatemala, highlights and new discoveries. Zootaxa 1839:1-42.

Elías-Gutiérrrez M, Suárez Morales E, Gutiérrez Aguirre M, Silva Briano M, Granados Ramírez JG, Garfias Espejo T, 2008b. [Cladocera y Copepoda de las aguas continentales de México. Guía ilustrada]. [Article in Spanish]. UNAM, CONABIO, ECOSUR, SEMARNAT-CONACYT ed., San Cristóbal de Las Casas: 322 pp.

Fischer S, 1854. [Abhandlung über einige neue oder nicht genau Bekannte Arten von Daphniden und Lynceiden als beitrag zur Fauna Russlands]. [Article in German]. Bull. Soc. Imp. Natur. Moscou 27:423-434.

Forró L, Korovchinsky NM, Kotov AA, Petrusek A, 2008. Global diversity of cladocerans (Cladocera; Crustacea) in freshwater. Hydrobiologia 595:177-184.

Frey DG, 1959. The taxonomic and phylogenetic significance of the head pores of the Chydoridae (Cladocera). Int. Rev. Ges. Hydrobio. 44:27-50.

Frey DG, 1973. Comparative morphology and biology of three species of Eurycercus (Chydoridae, Cladocera), with a descrip- tion of Eurycercus macracanthus sp. nov. Int. Rev. Ges. Hydrobio. 58:221-267.

Frey DG, 1982a. Questions concerning cosmopolitanism in Cladocera. Arch. Hydrobiol. 93:484-502.

Frey DG, 1982b. Relocation of Chydorus barroisi and related species (Cladocera, Chydoridae) to a new genus and description of two new species. Hydrobiologia 86:231-269.

Frey DG, 1987. The North American Chydorus faviformis (Cladocera, Chydoridae) and the honeycombed taxa of other continents. Philos. T. R. Soc. Lon. B 315:353-402.

Frey DG, 1988. Separation of Pleuroxus laevis Sars, 1861 from two species in North America: Pleuroxus straminius Birge, 1879 and Pleuroxus chiangi n. sp. (Cladocera, Chydoridae). Can. J. Zool. 66:2534-2563.

Gauthier H, 1939. [Contribution à l'étude de la Faune Dulçaquicole de la région du Tchad et particulièrement des branchiopodes et des ostracodes]. [Article in French]. Bull. Inst. Fond. Afr. Noire 1:110-244.

Goulden CE, 1968. The systematics and evolution of the Moinidae. T. Am. Philos. Soc. 58:1-101.

Havel JE, Hebert PDN, 1993. Daphnia lumholtzi in North America: another exotic zooplankter. Limnol. Oceanogr. 38:1823-1827.

Heckman CW, 1974. The seasonal succession of species in a rice paddy in Vientiane, Laos. Int. Rev. Ges. Hydrobio. 59:489-507.

Hudeč I, 2010. [Anomopoda, Ctenopoda, Haplopoda, Onychopoda (Crustacea: Branchiopoda). Fauna Slovenska III]. [Book in Slovenian]. VEDA, Bratislava: 496 pp.

Hudeč I, Illyová M, 1998. Pleuroxus denticulatus (Crustacea: Anomopoda: Chydoridae): a new invader in the Danube Basin. Hydrobiologia 368:65-73.

Idris BAG, 1983. Freshwater zooplankton of Malaysia (Crustacea: Cladocera). Perenbit University ed., Pertanian: 153 pp.

Idris BAG, Fernando CH, 1981. Two new species of cladoceran crustaceans of the genera Macrothrix Baird and Alona Baird from Malaysia. Hydrobiologia 76:81-85.

Jiang X, 1963. Description of two new species of Chinese freshwater Cladocera with notes on four new records. Acta Zool. Sinica 15:255-262.

King RL, 1853. On some Australian Entomostraca - in continuation. Pap. Proc. Roy. Soc. Tasmania 2:253-263.

Kiser R, 1948. Two new species of Alona from the Pearl River, Canton, China. T. Am. Microsc. Soc. 67:315-318.

Kořínek V, 2002. Cladocera, p. 69-122. In C.H. Fernando (ed.), A guide to tropical freshwater zooplankton. Backhuys Publ.

Korovchinsky NM, 1997. On the history of studies on cladoceran taxonomy and morphology, with emphasis on early work and causes of insufficient knowledge of the diversity of the group. Hydrobiologia 360:1-11.

Korovchinsky NM, 2004. Cladocerans of the order Ctenopoda of the world fauna (morphology, systematics, ecology, biogeography). KMK Press, Moscow: 410 pp.

Korovchinsky NM, 2010. A taxonomic revision of Pseudosida szalayi Daday, 1898 (Crustacea: Cladocera: Sididae) over its Asian range, with focus on the northernmost populations first recorded from the Amur River basin (Far East of Russia). Zootaxa 2345:1-18

Korovchinsky NM, 2013a. Cladocera (Crustacea: Branchiopoda) of South East Asia: history of exploration, taxon richness and notes on zoogeography. J. Limnol. 72(Suppl.2):e7.

Korovchinsky NM, 2013b. Sididae and other Cladocera (Crustacea: Branchiopoda) of North and West Thailand, with additional 
notes on Diaphanosoma senegal isanensis Korovchinsky et Sanoamuang, 2008. Annl. Limnol.-Int. J. Lim. (in press).

Kotov AA, 2009. A revision of Leydigia Kurz, 1875 (Anomopoda, Cladocera, Branchiopoda), and subgeneric differentiation within the genus. Zootaxa 2082:1-68.

Kotov AA, 2011. Crustacea-Cladocera checklist. Available from: http://fada.biodiversity.be/CheckLists/Crustacea-Cladocera.pdf

Kotov AA, Dumont HJ, 2000. Analysis of the Ilyocryptus spinifer s. lat. species group (Anomopoda, Branchiopoda), with description of a new species. Hydrobiologia 428:85-113.

Kotov AA, Garfias-Espejo T, Elías-Gutiérrez M, 2004. Separation of two Neotropical species: Macrothrix superaculeata (Smirnov, 1982) versus M. elegans Sars, 1901 (Macrothricidae, Anomopoda, Cladocera). Hydrobiologia 517:61-88.

Kotov AA, Ishida S, Taylor DJ, 2009. Revision of the genus Bosmina Baird, 1845 (Cladocera: Bosminidae), based on evidence from male morphological characters and molecular phylogenies. Zool. J. Linn. Soc. Lond. 156:1-56.

Kotov AA, Jeong HJ, Lee W, 2012. Cladocera (Crustacea: Branchiopoda) of the south-east of the Korean Peninsula, with twenty new records for Korea. Zootaxa 3368:50-90.

Kotov AA, Korovchinsky NM, Sinev AY, Smirnov NN, 2011. Cladocera (Crustacea, Branchiopoda) of the Zeya basin (Amurskaya Area, Russian Federation). 3. Systematic-faunistic and zoogeographic analysis. Zool. Zh. 90:402-411.

Kotov AA, Maiphae S, Sanoamuang L, 2005. Revision of Macrothrix paulensis-like species (Anomopoda, Cladocera, Branchiopoda) in Asia, and phylogeny of the paulensis-group. Arch. Hydrobiol. 151:269-299.

Kotov AA, Sanoamuang L, 2004a. Comments on the morphology of Nicsmirnovius eximius (Kiser, 1948) (Aloninae, Anomopoda, Cladocera) in Thailand, with a description of its male. Hydrobiologia 519:117-125.

Kotov AA, Sanoamuang L, 2004b. Ilyocryptus thailandensis sp. nov. (Cladocera: Anomopoda: Ilyocryptidae) from North Thailand. Int. Rev. Hydrobiol. 89:206-214.

Kotov AA, Van Damme K, Elías-Gutiérrez M, 2003. Differentiation between African Leydigia ciliata Gauthier, 1939 and Neotropical L. cf. striata Birabeén, 1939 (Chydoridae, Anomopoda, Cladocera). Hydrobiologia 505:179-197.

Maiphae S, 2005. Taxonomy and biogeography of the Cladocera from Southern Thailand, with specific reference to Alona Baird, 1843 and Macrothrix Baird, 1843. PhD thesis. Prince of Songkla University ed., Hat Yai: 314 pp.

Maiphae S, Pholpunthin P, Dumont HJ, 2005. Species richness of the Cladocera (Branchiopoda: Anomopoda and Ctenopoda) in southern Thailand, and its complementarity with neighboring regions. Hydrobiologia 537:147-156.

Maiphae S, Pholpunthin P, Dumont HJ, 2008. Taxon richness and biogeography of the Cladocera (Crustacea, Ctenopoda, Anomopoda) of Thailand. Ann. Limnol.-Int. J. Lim. 44:33-43.

Orlova-Bienkowskaja MY, 2001. Daphniidae: genus Simocephalus. Guides to the identification of the microinvertebrates of the continental waters of the World, 17. Backhuys, Leyden: $130 \mathrm{pp}$.

Pholpunthin P, 1997. Freshwater zooplankton (Rotifera, Cladocera and Copepoda) from Thale-Noi, South Thailand. J. Sci. Soc. Thailand 23:23-34.

Pirozhnikov PL, 1937. [Zooplankton of the Yenisey River and Yenisey Bay and its role in the fish feeding]. [Article in Russian]. Trudy Vsesoyuznogo Arkticheskogo Instituta 98:1-61.

Ponthalith C, 2006. Species diversity and distribution of Cladocera in Champasak Province, Lao PDR. Degree Thesis. Khon Kaen University ed., Khon Kaen: 73 pp.

Rajapaksa R, Fernando CH, 1982. The first description of the male and ephippial female of Dadaya macrops (Daday, 1898) (Cladocera. Chydoridae), with additional notes on this common tropical species. Can. J. Zool. 60:1841-1850.

Rajapaksa R, Fernando CH, 1985. Reallocation of Indialona macronyx (Daday, 1898) (Cladocera, Chydoridae) to the genus Alona. Can. J. Zool. 63:970-976.

Rajapaksa R, Fernando CH, 1986. Tropical species of Kurzia (Crustacea, Cladocera), with a description of Kurzia brevilabris sp. nov. Can. J. Zool. 64:2590-2602.

Rajapaksa R, Fernando CH, 1987a. A note on Alona macronyx Daday, 1898 (Crustacea, Cladocera), a rare species from the Oriental region. Can. J. Zool. 65:216-218.

Rajapaksa R, Fernando CH, 1987b. A redescription of Euryalona orientalis (Daday, 1898), with a consideration of the other species in the genus Euryalona (Cladocera: Chydoridae). Hydrobiologia 150:75-90.

Rajapaksa R, Fernando CH, 1987c. Redescription and assignment of Alona globulosa Daday, 1898 to a new genus Notoalona and a description of Notoalona freyi sp. nov. Hydrobiologia 144:131-153.

Rajapaksa R, Fernando CH, 1987d. Redescription of Dunhevedia serrata Daday, 1898 (Cladocera, Chydoridae) and a description of Dunhevedia americana sp. nov. from America. Can. J. Zool. 65:432-440.

Richard J, 1894. [Cladocères recueillis par le Dr. Théod. Barrois en Palestine, en Syrie et en Égypte]. [Article in French]. Rev. Biol. Nord France 6:360-378.

Sanoamuang L, 1998. Contributions to the knowledge of the Cladocera of north-east Thailand. Hydrobiologia 362:45-53.

Sars GO, 1862. [Hr. Studios medic. G. O. Sars meddeelte en af talrige Afbildninger ledsaget Oversigt af de af ham i Omegnen af Christiania iagttagne Crustacea cladocera]. [Article in Danish]. Forh. VidenskSelsk. Krist. 1861:144-167.

Sars GO, 1901. Contributions to the knowledge of the fresh-water Entomostraca of South America, as shown by artificial hatching from dried material. 1. Cladocera. Arch. Math. Naturvidensk 23:1-102.

Schabetsberger R, Drozdowski G, Rott E, Lenzenweger R, Jersabek CD, Fiers F, Traunspurger W, Reiff N, Stoch F, Kotov AA, Martens K, Schatz H, Kaiser R, 2009. Losing the bounty? Investigating species richness in isolated freshwater ecosystems of Oceania. Pac. Sci. 63:153-179.

Sharma P, Kotov AA, 2013. Molecular approach to identify sibling species within Ceriodaphnia cornuta species group (Cladocera: Daphniidae) from Australia with notes on the continental endemism of this group. Zootaxa 3702:79-89.

Shirota A, 1966. The plankton of South Viet-Nam. Freshwater and marine plankton. Overseas Techn. Coop. Agency ed., Tokyo, Japan: 489 pp.

Silva-Briano M, Dieu NQ, Dumont HJ, 1999. Redescription of Macrothrix laticornis (Jurine, 1820), and description of two new species of the M. laticornis-group. Hydrobiologia 403:39-61

Silva-Briano M, Sanoamuang L, Ortiz AA, Galvan de la Rosa R, 2005. Remarks on the Anomopoda and Ctenopoda (Cladocera) from Central Laos, p. 44. In P. Spaak (ed.), $7^{\text {th }}$ International Symposium on Cladocera, September 3-9, 2005, Herzberg, Switzerland. 
Sinev AY, 1997. Review of the affinis-group of Alona Baird, 1843, with the description of a new species from Australia (Anomopoda Chydoridae). Arthropoda Sel. 6:47-58.

Sinev AY, 1999. Alona costata Sars, 1862 versus related palaeotropical species: the first example of close relations between species with a different number of main head pores among Chydoridae (Crustacea: Anomopoda). Arhropoda Sel. 8:131-148.

Sinev AY, 2001. Separation of Alona cambouei Guerne and Richard, 1893 from Alona pulchella King, 1853 (Branchiopoda: Anomopoda: Chydoridae). Arthropoda Sel. 10:5-18.

Sinev AY, 2004. Redescription of a South American cladocera, Alona monacantha Sars, 1901 (Branchiopoda: Anomopoda: Chydoridae). Arthropoda Sel. 13:7-12.

Sinev AY, 2008. A new species related to Alona costata Sars, 1862 (Cladocera: Anomopoda: Chydoridae) from South Africa. Zootaxa 1707:23-36.

Sinev AY, 2009. Discrimination between two sibling species of Acroperus (Baird, 1843) from the Palearctic (Cladocera: Anomopoda: Chydoridae). Zootaxa 2176:1-21.

Sinev AY, 2011. Redescription of the rheophilous cladocera Camptocercus vietnamensis Than, 1980 (Cladocera: Anomopoda: Chydoridae). Zootaxa 2934:53-60.

Sinev AY, 2012. Alona kotovi sp. nov., a new species of Aloninae (Cladocera: Anomopoda: Chydoridae) from South Vietnam. Zootaxa 3475:45-54.

Sinev AY, Korovchinsky NM, 2013. Cladocera (Crustacea: Branchiopoda) of Cat Tien National Park, South Vietnam. J. Limnol. 72(Suppl.2):e8.

Sinev AY, Kotov AA, 2012. New and rare Aloninae (Cladocera: Anomopoda: Chydoridae) from Indochina. Zootaxa 3334:128.

Sinev AY, Sanoamuang L, 2007. Alona siamensis sp.n., a new species of Cladocera from South-East Asia, related to Alona dentifera (Sars, 1901) (Anomopoda: Chydoridae). Arthropoda Sel. 16:143-150.

Sinev AY, Sanoamuang L, 2011. Hormonal induction of males as a method for studying tropical cladocerans: description of males of four chydorid species (Cladocera: Anomopoda: Chydoridae). Zootaxa 2826:45-56.

Sinev AY, Van Damme K, Kotov AA, 2005. Redescription of tropical-temperate cladocerans Alona diaphana King, 1853 and Alona davidi Richard, 1895 and their translocation to Leberis Smirnov, 1989 (Branchiopoda: Anomopoda: Chydoridae). Arthropoda Sel. 14:183-205.

Smirnov NN, 1966. The taxonomic significance of the trunk limbs of the Chydoridae (Cladocera). Hydrobiologia 27:337-347.

Smirnov NN, 1971. Chydoridae of the world fauna. Fauna SSSR. Rakoobraznye 1:1-531.

Smirnov NN, 1976. Macrothricidae and Moinidae of the world fauna. Fauna SSSR. Rakoobraznye 1:1-237.

Smirnov NN, 1996. Cladocera: the Chydorinae and Sayciinae (Chydoridae) of the world. Guides to the identification of the microinvertebrates of the continental waters of the world. SPB Acad. Publ., Amsterdam: 197 pp.

Smirnov NN, Kotov AA, Coronel J, 2006. Partial revision of the aduncus-like species of Pleuroxus Baird, 1843 (Chydoridae, Cladocera) from the southern hemisphere with comments of subgeneric differentiation within the genus. J. Nat. Hist. 40:1617-1639.

Tanaka S, Ohtaka A, 2010. Freshwater Cladocera (Crustacea, Branchiopoda) in Lake Tonle Sap and its adjacent waters in Cambodia. Limnology 11:171-178.

Thanh DN, Bai TT, Mien PV, 1980. The freshwater invertebrates of North Vietnam. Science and Technology Publ., Hanoi: 573 pp.

Van Damme K, Chiambeng G, Maiphae S, Dumont HJ, 2003. New species in the rheophilous genus Nicsmirnovius Chiambeng and Dumont, 1999 (Branchiopoda: Anomopoda: Chydoridae) and reassignment of Alona eximia Kiser, 1948 and Alonella fitzpatricki Chien, 1970. Hydrobiologia 499:25-49.

Van Damme K, Dumont HJ, 2008a. Further division of Alona Baird, 1843: separation and position of Coronatella Dybowski and Grochowski and Ovalona gen. n. (Crustacea: Cladocera). Zootaxa 1960:1-44.

Van Damme K, Dumont HJ, 2008b. The 'true' genus Alona Baird, 1843 (Crustacea: Cladocera: Anomopoda): characters of the $A$. quadrangularis-group and description of a new species from Democratic Republic Congo. Zootaxa 1945:1-25.

Van Damme K, Dumont HJ, 2009. Notes on chydorid endemism in continental Africa: Matralona gen. n., a monotypic Alonine from the Fouta Djalon Plateau (Guinea, West Africa) (Crustacea: Cladocera: Anomopoda). Zootaxa 2051:26-40.

Van Damme K, Dumont HJ, 2010. Cladocera of the Lençóis Maranhenses (NE - Brazil): faunal composition and a reappraisal of Sars' method. Braz. J. Biol. 70:755-779.

Van Damme K, Kotov AA, Dumont HJ, 2010. A checklist of names in Alona Baird 1843 (Crustacea: Cladocera: Chydoridae) and their current status: an analysis of the taxonomy of a lump genus. Zootaxa 2330:1-63.

Van Damme K, Maiphae S, 2013. Salinalona gen. nov., an euryhaline chydorid lineage (Crustacea: Branchiopoda: Cladocera: Anomopoda) from the Oriental region. J. Limnol. 72(Suppl.2):e9.

Van Damme K, Maiphae S, Sa-ardrit P, 2013. Inland swamps in South East Asia harbour hidden cladoceran diversities: species richness and the description of new paludal Chydoridae (Crustacea: Branchiopoda: Cladocera) from Southern Thailand. J. Limnol. 72(Suppl.2):e10.

Van Damme K, Sinev AY, 2013. Tropical Amphi-Pacific disjunctions in the Cladocera (Crustacea: Branchiopoda). J. Limnol. 72(Suppl.2):e11.

Van Damme K, Sinev AY, Dumont HJ, 2011. Separation of Anthalona gen.n. from Alona Baird, 1843 (Branchiopoda: Cladocera: Anomopoda): morphology and evolution of scraping stenothermic alonines. Zootaxa 2875:1-64.

Venkataraman K, 1999. Resurrection of Biapertura kwangsiensis (Chiang 1963) from Biapertura karua (King 1853) (Crustacea: Cladocera). J. Bombay Nat. Hist. Soc. 96:347-353.

Wikipedia, 2013. Laos. Available from: http://en.wikipedia. org/wiki/Laos

Yoon SM, 2010. [Branchiopods: Arthropoda: Branchiopoda: Anostraca, Notostraca, Spinicaudata, Laevicaudata, Ctenopoda, Anomopoda, Haplopoda]. [Book in Korean]. Korean Government Publ., Pyongyang: 156 pp. 